\title{
Bathymetric controls on sediment transport in the Hudson River estuary: Lateral asymmetry and frontal trapping
}

\author{
David K. Ralston, ${ }^{1}$ W. Rockwell Geyer, ${ }^{1}$ and John C. Warner ${ }^{2}$ \\ Received 7 April 2012; revised 24 August 2012; accepted 6 September 2012; published 17 October 2012.
}

[1] Analyses of field observations and numerical model results have identified that sediment transport in the Hudson River estuary is laterally segregated between channel and shoals, features frontal trapping at multiple locations along the estuary, and varies significantly over the spring-neap tidal cycle. Lateral gradients in depth, and therefore baroclinic pressure gradient and stratification, control the lateral distribution of sediment transport. Within the saline estuary, sediment fluxes are strongly landward in the channel and seaward on the shoals. At multiple locations, bottom salinity fronts form at bathymetric transitions in width or depth. Sediment convergences near the fronts create local maxima in suspended-sediment concentration and deposition, providing a general mechanism for creation of secondary estuarine turbidity maxima at bathymetric transitions. The lateral bathymetry also affects the spring-neap cycle of sediment suspension and deposition. In regions with broad, shallow shoals, the shoals are erosional and the channel is depositional during neap tides, with the opposite pattern during spring tides. Narrower, deeper shoals are depositional during neaps and erosional during springs. In each case, the lateral transfer is from regions of higher to lower bed stress, and depends on the elevation of the pycnocline relative to the bed. Collectively, the results indicate that lateral and along-channel gradients in bathymetry and thus stratification, bed stress, and sediment flux lead to an unsteady, heterogeneous distribution of sediment transport and trapping along the estuary rather than trapping solely at a turbidity maximum at the limit of the salinity intrusion.

Citation: Ralston, D. K., W. R. Geyer, and J. C. Warner (2012), Bathymetric controls on sediment transport in the Hudson River estuary: Lateral asymmetry and frontal trapping, J. Geophys. Res., 117, C10013, doi:10.1029/2012JC008124.

\section{Introduction}

[2] Estuaries efficiently trap and accumulate sediment from both the watershed and coastal ocean [Schubel and Hirschberg, 1978]. An important trapping mechanism is the near-bottom velocity convergence due to along-estuary gradients in the baroclinic pressure gradient, which creates regions of enhanced suspended-sediment concentration (SSC) and deposition [Postma, 1967; Meade, 1969]. The estuarine turbidity maximum (ETM) typically is associated with the landward extent of the salinity intrusion, where the salinity gradient and estuarine circulation go to zero. Nearbottom estuarine circulation is landward within the salinity intrusion while mean river flow in the tidal freshwater region is seaward; this near-bottom flow convergence combined

\footnotetext{
${ }^{1}$ Applied Ocean Physics and Engineering Department, Woods Hole Oceanographic Institution, Woods Hole, Massachusetts, USA.

${ }^{2}$ Woods Hole Coastal and Marine Science Center, U.S. Geological Survey, Woods Hole, Massachusetts, USA.

Corresponding author: D. K. Ralston, Applied Ocean Physics and Engineering Department, Woods Hole Oceanographic Institution, MS \#11, Woods Hole, MA 02543, USA. (dralston@whoi.edu, Tel.: 508-289-2587, Fax: 508-457-2194)

C2012. American Geophysical Union. All Rights Reserved. 0148-0227/12/2012JC008124
}

with sediment settling creates a local maximum in SSC at the head of salt. In addition to the baroclinic flow convergence, other mechanisms such as asymmetries in stratification [Hamblin, 1989; Geyer, 1993], and velocity shear [Jay and Musiak, 1994; Burchard and Baumert, 1998] can contribute to the formation of an ETM at the head of the salinity intrusion. Disentangling these various mechanisms remains a challenging problem, but the results presented here suggest that the along-estuary variation in salinity gradient and stratification that create an ETM at the head of salt also occur at bottom salinity fronts at multiple locations within the salinity distribution.

[3] Secondary ETMs have been observed at locations distinct from the head of salinity intrusion, and can be linked with bathymetric transitions in width or depth [Nichols, 1972; Roberts and Pierce, 1976; Jay and Musiak, 1994; Schoellhamer, 2000; Lin and Kuo, 2001; Fugate et al., 2007; Kim and Voulgaris, 2008]. For example in the Hudson River estuary, the most prominent ETM is located near a constriction at intermediate salinities [Geyer et al., 1998]. In Chesapeake Bay, topographically fixed secondary ETMs at bathymetric transitions have been linked to tidal asymmetries in stratification [North and Houde, 2001; Fugate et al., 2007]. Similarly, along-estuary gradients in stratification associated with bathymetric features in the York 
River were associated with secondary ETMs [Lin and Kuo, 2001]. Secondary ETMs may have lateral structure, such that the region of high turbidity and deposition associated with the sediment flux convergence extends seaward along the channel banks [Nichols, 1972].

[4] The processes that lead to sediment trapping, whether baroclinic convergence, stratification asymmetry, or tidal shear asymmetry, all depend on water depth. In the channel thalweg, the baroclinic circulation, stratification, and shear asymmetries are stronger and sediment is trapped more effectively than on adjacent shoals. On the shoals, the estuarine circulation and stratification are weaker and the river outflow has a greater influence on the near-bed mean flow. The importance of lateral bathymetric variations to sediment transport was noted in the coastal plain sub-estuaries of Chesapeake Bay, where net sediment fluxes tended to be seaward on the shoals and landward in deeper channels [Nichols and Poor, 1967; Nichols, 1972]. A simplified model of the Hudson River estuary similarly found that long-term (seasonal to interannual) average sediment fluxes were landward in the channel, and that channel export during intermittent high discharge events was insufficient to balance watershed sediment input [Ralston and Geyer, 2009]. In contrast, sediment fluxes on the shoals were seaward, providing a transport pathway that, as is discussed later, may be important for maintaining morphodynamic equilibrium. Lateral asymmetries in sediment flux, with landward transport in the channel and seaward transport on the shoals, have been observed in the lower Hudson [Panuzio, 1965] and York River estuaries [Scully and Friedrichs, 2007], and in the Delaware estuary channel fluxes were landward while transport on the shoals was variable [Sommerfield and Wong, 2011].

[5] The goal of this work is to assess how bathymetric variability affects sediment transport in a partially stratified estuary. Along-estuary bathymetric transitions and lateral depth variation between channel and shoal create spatial gradients in residual circulation and stratification, and thus affect sediment transport and deposition. We use observations and a numerical model to evaluate sediment transport in the Hudson River estuary. The results suggest that bathymetric complexity alters the conceptual framework of 2-d, along-channel estuary with sediment trapping primarily at the head of salt, and that instead localized regions of trapping occur at multiple bathymetric transitions along the salinity gradient, and that the lateral differences in depth between channel and shoal determine the direction of net sediment flux.

\section{Methods}

\subsection{Study Location}

[6] The research approach combined field observations with a numerical model of hydrodynamics and sediment transport in the Hudson River estuary. The Hudson River is tidal from the Battery at the southern end of Manhattan to Troy, NY, $240 \mathrm{~km}$ to the north (Figure 1).The tidal limit is near the confluence of the Mohawk and upper Hudson Rivers, which together provide annual average discharge of $\sim 400 \mathrm{~m}^{3}$ $\mathrm{s}^{-1}$. Additional tributaries enter the Hudson downstream of the tidal limit, increasing the total flow by 30 to $60 \%$ [Lerczak et al., 2006; Wall et al., 2008]. Maximum discharges usually occur during the spring snowmelt freshet, although recent observations have noted an increase in discharge events associated with fall and winter storms [Wall et al., 2008].The seasonal variability in discharge typically ranges from peaks around $2,000 \mathrm{~m}^{3} \mathrm{~s}^{-1}$ during the spring freshet to summer low flows around $200 \mathrm{~m}^{3} \mathrm{~s}^{-1}$.

[7] Estimates of annual sediment supply from the Hudson River vary from 0.2 to 1.0 million metric tons [Panuzio, 1965; Olsen, 1979; Ellsworth, 1986; Woodruff, 1999; Wall et al., 2008], and tributaries downstream of the Mohawk and upper Hudson Rivers increase the sediment load by 30 to 40 percent [Wall et al., 2008]. Within the estuary, the most prominent ETM is located near the George Washington Bridge, $\sim 12$ to $25 \mathrm{~km}$ north of the Battery, where near-bed concentrations greater than $1000 \mathrm{mg} \mathrm{L}^{-1}$ have been observed during strong river and tidal forcing [Geyer et al., 2001; Traykovski et al., 2004]. Limited observations have suggested that ETMs in the upper estuary may be associated with the head of the salinity intrusion or with bathymetric features. The observational focus in this study was on Haverstraw Bay, about $60 \mathrm{~km}$ from the Battery (Figure 1). Haverstraw Bay is the widest part of the estuary $(\sim 6 \mathrm{~km})$, with a relatively narrow channel $(\sim 1 \mathrm{~km})$ that is 8 to $12 \mathrm{~m}$ deep and broad shoals that are 2 to $3 \mathrm{~m}$ deep. During summer low discharge conditions, high sediment concentrations were observed in Haverstraw Bay [Bokuniewicz and Arnold, 1984], and high accumulation rates of mud and toxic metals there have been linked to high near-bed sediment concentrations [Menon et al., 1998]. Seismic surveys and sediment cores indicate that Haverstraw Bay is highly depositional, particularly in a section of the navigational channel that is periodically dredged [Nitsche et al., 2007, 2010].

\subsection{Observations}

[8] The study focused on conditions during the fall, when intermittent storms increase river discharge and sediment delivery [Wall et al., 2008]. Fixed instrument frames were deployed from 21 September to 9 December 2009. In Haverstraw Bay, instruments focused on near-bottom measurements were deployed in the channel and on the shoal (Figure 1d). The mean depths at the channel and shoal stations were $8 \mathrm{~m}$ and $3 \mathrm{~m}$, respectively. Each frame had conductivity-temperature (CT) sensors and optical backscatter sensors (OBS) at multiple elevations between 0.3 and $1.3 \mathrm{~m}$ above the bed (mab). Acoustic Doppler velocimeters were mounted 0.4 and 1.0 mab to measure currents and turbulent fluctuations at discrete elevations, and a downward-looking pulse-coherent Doppler profiler measured velocity and acoustic backscatter in $1 \mathrm{~cm}$ bins over the bottom $1 \mathrm{~m}$. Over the same range, acoustic backscatter sensors profiled at 3 frequencies: 1, 2.5, and $5 \mathrm{MHz}$. An upward-looking acoustic Doppler current profiler $(0.7 \mathrm{mab})$ measured velocity and acoustic backscatter over the water column. A surface buoy fitted with CT and OBS sensors for near-surface water properties was deployed with each frame, and the channel buoy had a meteorological instrument package to measure wind speed and direction, barometric pressure, and air temperature.

[9] Calibrations of the optical and acoustic backscatter sensors to SSC were based on water samples collected during tidal cycle surveys in Haverstraw in October 2009. 

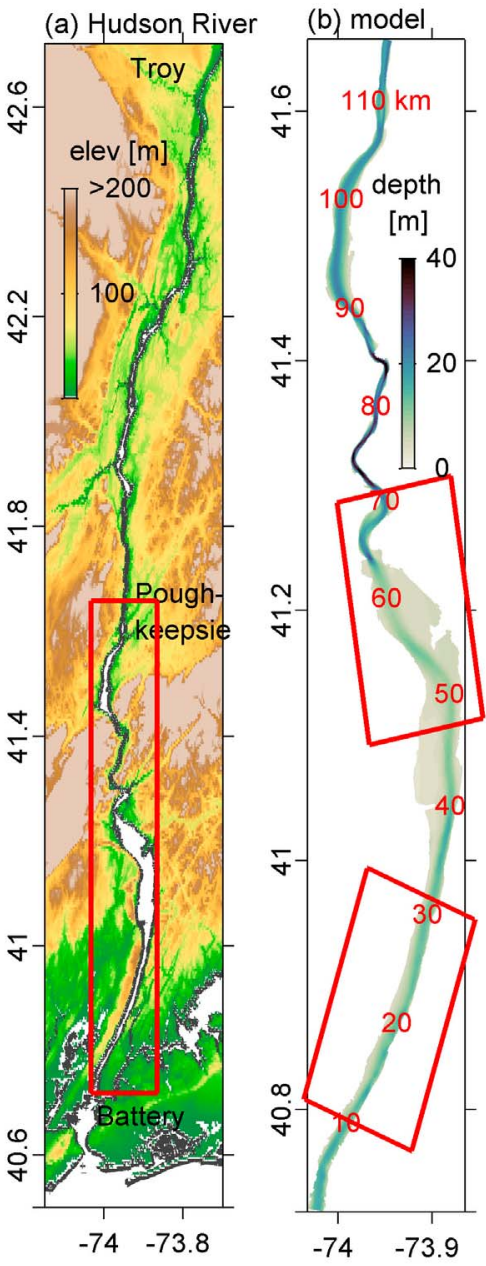

(c) lower estuary

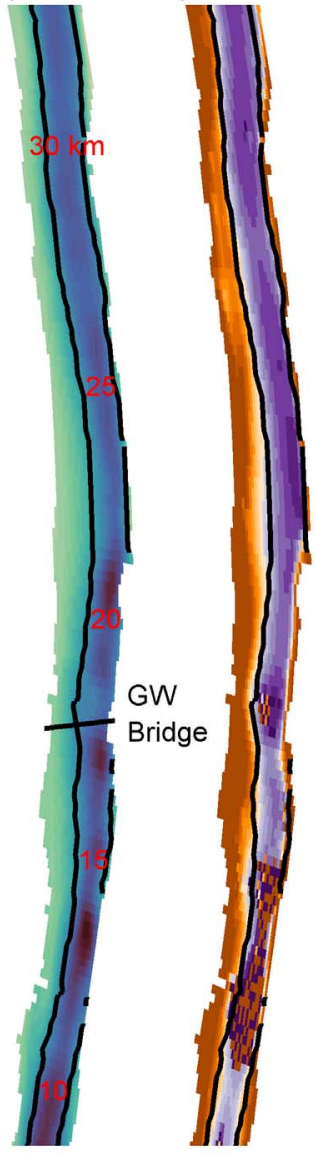

(d) upper estuary

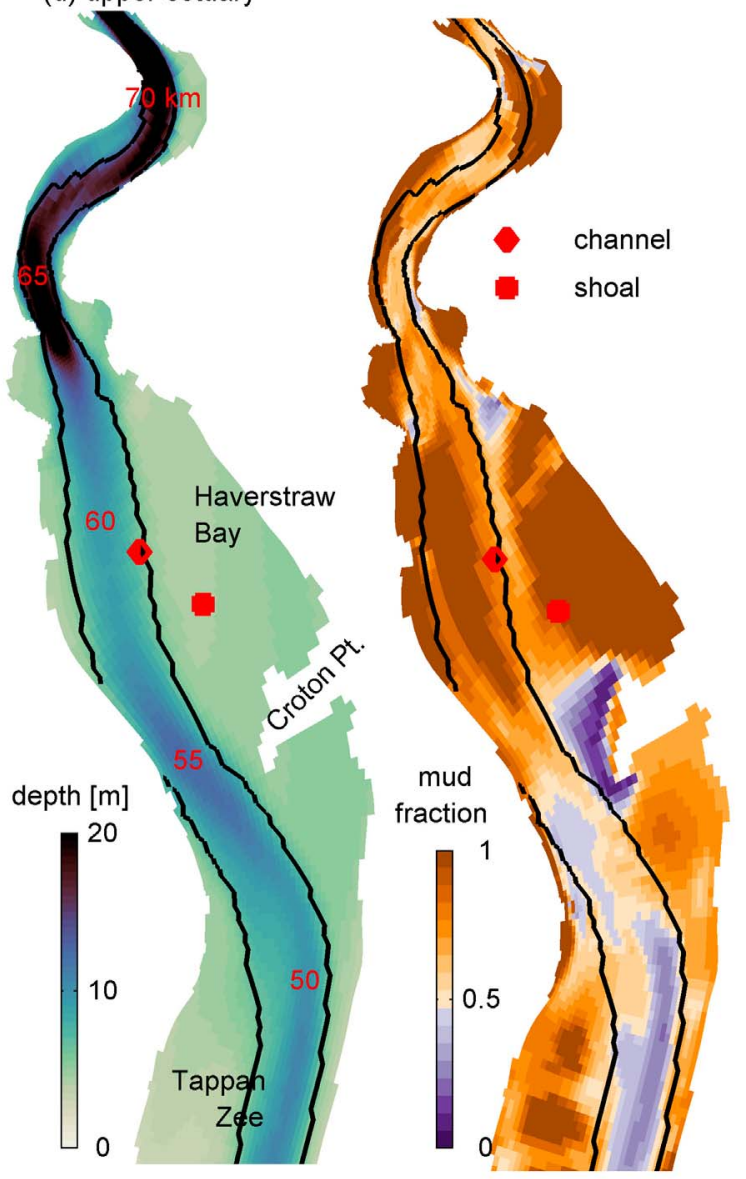

Figure 1. Map of the study area. (a) Tidal reach of the Hudson River from the Battery in Manhattan to Troy, NY. The USGS station at Green Island (01358000) is immediately upstream from the dam at Troy. Red box marks the model domain shown in Figure 1b. Elevation from USGS National Elevation Data set. (b) Model domain, from the Battery to Poughkeepsie. (c) Bathymetry (left) and initial bed sediment composition as the fraction in the mud size class (right) in the region of the lower ETM, noting the location of the George Washington (GW) Bridge. (d) Bathymetry (left) and initial bed sediment composition (right) in Haverstraw Bay, with locations of channel and shoal instrument frames marked in red. Along-estuary distance $(\mathrm{km})$ shown in red in Figures 1b, 1c, and 1d. The black contours in Figures 1c and 1d denote the boundary between the "channel" and "shoal" regions used in the analysis, based on depth relative to the cross-sectional mean.

Water samples were collected near the instrument frames with a Niskin sampler triggered at $50 \mathrm{~cm}$ above the bed. Samples were filtered, dried, and weighed in the lab. Measured sediment concentrations were plotted against the backscatter measurements to derive calibration curves. The uncertainty in the resulting SSC time series is perhaps a factor of 50 percent, because the regression coefficients for the calibrations were modest $\left(\mathrm{r}^{2}=0.38\right.$ for the near-bottom OBS in the channel, $\mathrm{r}^{2}=0.71$ for the near-bottom OBS on the shoals), the number of bottle samples was small (20), and the maximum concentrations observed in the bottle samples ( $\sim 70 \mathrm{mg} \mathrm{L}^{-1}$ ) were lower than the maximum concentrations in the time series $\left(\sim 400 \mathrm{mg} \mathrm{L}^{-1}\right)$. The near-bottom acoustic and OBS measurements corresponded with each other, with $\mathrm{r}^{2}$ of 0.50 in the channel and 0.70 on the shoals.

\subsection{Numerical Model}

[10] The Regional Ocean Modeling System (ROMS) was used to solve the 3-d Reynolds-averaged Navier-Stokes equations on a curvilinear finite difference grid with a stretched terrain-following vertical coordinate [Shchepetkin and McWilliams, 2005; Haidvogel et al., 2008]. The sediment transport model was the Community Sediment Transport Modeling System (CSTMS) that is integrated into ROMS [Warner et al., 2008]. The model grid extended from the Battery to Poughkeepsie, about $120 \mathrm{~km}$ up-estuary (Figure 1). The grid was a higher resolution version of a model that previously had been evaluated against time series of salinity and velocity at multiple locations along the Hudson [Warner et al., 2005]. The newer grid was 38 cells wide by 622 cells along-estuary, such that the lateral 
Table 1. Model Sediment Properties

\begin{tabular}{lccc}
\hline \multicolumn{1}{c}{$\begin{array}{c}\text { Sediment } \\
\text { Class }\end{array}$} & $\begin{array}{c}\text { Settling } \\
\text { Velocity } \\
\left(\mathrm{mm} \mathrm{s}^{-1}\right)\end{array}$ & $\begin{array}{c}\text { Erosion } \\
\text { Rate } \\
\left(\mathrm{kg} \mathrm{m}^{-2} \mathrm{~s}^{-1}\right)\end{array}$ & $\begin{array}{c}\text { Critical Stress } \\
\text { for Erosion } \\
\left(\mathrm{N} \mathrm{m}^{-2}\right)\end{array}$ \\
\hline 1. Medium sand (bed) & 40. & $1 \times 10^{-4}$ & 0.5 \\
2. Fine sand (bed) & 5. & $1 \times 10^{-4}$ & 0.1 \\
3. Silt (bed) & 0.6 & $1 \times 10^{-4}$ & 0.05 \\
4. Silt (river) & $0.1,^{\mathrm{a}} 0.6$ & $1 \times 10^{-3}, 1 \times 10^{-4}$ & 0.05 \\
\hline
\end{tabular}

${ }^{\mathrm{a}}$ Properties where salinity $<0.5 \mathrm{psu}$. Sediment from the river has a slower settling velocity and higher erosion rate in fresh water to represent unfloculated particles, and it has properties equal to the silt fraction of the bed where salinity $>0.5$ psu.

resolution was 15 to $140 \mathrm{~m}$ (median of $50 \mathrm{~m}$ ) and the alongestuary grid spacing was 50 to $400 \mathrm{~m}$ (median of $180 \mathrm{~m}$ ). The grid had 16 sigma layers in the vertical. The southern boundary was forced by the water surface measured at the Battery (NOAA 8518750), and the northern boundary was forced with volume fluxes observed at Poughkeepsie (USGS 01372058). The salinity and horizontal salinity gradient at the southern boundary were based on a hyperbolic tangent function fit to the along-channel salinity distribution, as in Warner et al. [2005]. Salinity at the northern boundary was set to zero. Surface wind stresses were calculated in ROMS using observed wind speeds at the meteorological buoy in Haverstraw Bay. Winds at the buoy correlated well with data from the northern and southern limits of the domain (Newark airport, WBAN 14734, $\mathrm{r}^{2}=0.78$, and Poughkeepsie, USGS 01372058, $r^{2}=0.62$ ), so we assumed uniform windforcing.

[11] The sediment model incorporated four sediment classes: three in the initial bed composition representing medium sand, fine sand, and silt, and one input at the river boundary representing silt (Table 1). Sediment erosion and deposition fluxes at the bottom boundary were formulated as in Warner et al. [2008]. SSC at the river boundary was based on observed cross-sectional average concentrations at Poughkeepsie (USGS 01372058), and typically ranged between 20 and $50 \mathrm{mg} \mathrm{L}^{-1}$. The initial bed sediment distribution was derived from benthic mapping of the Hudson using side scan sonar [Nitsche et al., 2007]. Bottom type classification maps from the benthic surveys were projected onto the model grid and associated with the bed sediment classes (Table 1). To minimize spin-up, this initial bed sediment distribution was allowed to evolve over a model run of 100 days using realistic forcing. The sediment bed resulting from the 100 day run then was used to initialize the simulations analyzed in this study (Figure 1).

\section{Results}

\subsection{Observations}

[12] During the observations, discharge in the Hudson River ranged from less than $200 \mathrm{~m}^{3} \mathrm{~s}^{-1}$, typical of late summer low flows, to about $1200 \mathrm{~m}^{3} \mathrm{~s}^{-1}$ after a storm event (Figure 2a). The tidally filtered volume flux at Poughkeepsie includes the variations in freshwater discharge from upstream, but it also is affected by meteorological time scale fluctuations with changes in water surface elevation at the coastal boundary (Figure 2a). These synoptic volume fluxes can enhance or retard the mean river flow in the estuary, altering salt and sediment transport over periods of several days [Ralston et al., 2008]. The observation period spanned about 5 spring-neap cycles of varying magnitude (Figure 2b).

[13] The analyses presented here focus on a few aspects of the observations, highlighting dominant physical processes with relevance to sediment transport. Beginning with salinity, stratification varied significantly both spatially and temporally. In the channel, stratification varied with the spring-neap tidal cycle, while the shoals were often wellmixed (Figure 2c). Bottom salinity in the channel ranged between nearly fresh and about 15 psu, with salinity decreasing during spring tides and increasing during neaps with the retreat and advance of the salinity intrusion. Stratification was greatest ( $>10 \mathrm{psu}$, surface-to-bottom) during neap tides and was nearly eliminated $(<1 \mathrm{psu})$ during spring tides. The shoals were well-mixed during both spring and neap tides, with stratification typically $<1 \mathrm{psu}$, although the depth-mean salinity varied with the spring-neap movement of the salinity intrusion.

[14] Suspended-sediment concentrations generally were greater in the channel than on the shoals in Haverstraw Bay (Figure 2d). Typical tidal maximum SSC in the channel ranged between 50 and $400 \mathrm{mg} \mathrm{L}^{-1}$, with higher concentrations after the discharge event around day 300 . On the shoals, the tidal maximum sediment concentrations were lower, typically 20 to $80 \mathrm{mg} \mathrm{L}^{-1}$. SSC on the shoals increased with tidal amplitude, with higher concentrations during spring tides, but the highest SSC in the channel occurred during neap tides. As discussed later in the Results, these high sediment concentrations in the channel appear to be due to frontal trapping and subsequent advection from seaward of the instrument location.

[15] The lateral differences in stratification and sediment concentration were apparent during a transition between spring and neap tides (Figure 3). In the channel, the shift from unstratified spring tides to stratified neaps was not gradual, but rather was punctuated by sharp increases in near-bottom salinity during flood tides (Figure 3a). These rapid increases in bottom salinity corresponded with sharp spatial gradients. Approximating the salinity equation as a balance between advection and unsteadiness, we estimate the along-estuary salinity gradient $(\partial s / \partial x)$ in the channel from the time series of near bottom salinity and velocity $\left(u_{b}\right)$ : $\partial s / \partial x \approx u_{b}^{-1}(\partial s / \partial t)$. This approach neglects vertical mixing and lateral advection, but over short periods ( $\mathrm{dt} \sim 15 \mathrm{~min}$.) those terms are expected to be small compared with alongchannel advection. Assuming this balance holds, $\partial s / \partial x$ calculated in the channel at the fronts during neap tides was in the range of 10 to $80 \mathrm{psu} \mathrm{km}^{-1}$, two orders of magnitude greater than the average gradient for the salinity intrusion (e.g., $20 \mathrm{psu} / 70 \mathrm{~km} \approx 0.3 \mathrm{psu} \mathrm{km} \mathrm{km}^{-1}$ ).

[16] Associated with each of the salinity fronts at the channel station was a sharp increase in SSC (Figure 3b). In fact, the highest sediment concentrations observed were in these neap, flood-tide salinity fronts. In contrast during neap ebbs, maximum concentrations in the channel were much lower. The near-bottom velocities in the channel during neap tides were also tidally asymmetric (Figure 3c). During neap flood tides, near-bottom velocities were similar to, or at times greater than, the depth- averaged velocity, consistent with minimal velocity shear and a subsurface velocity maximum. During neap ebbs, near-bottom velocities were 

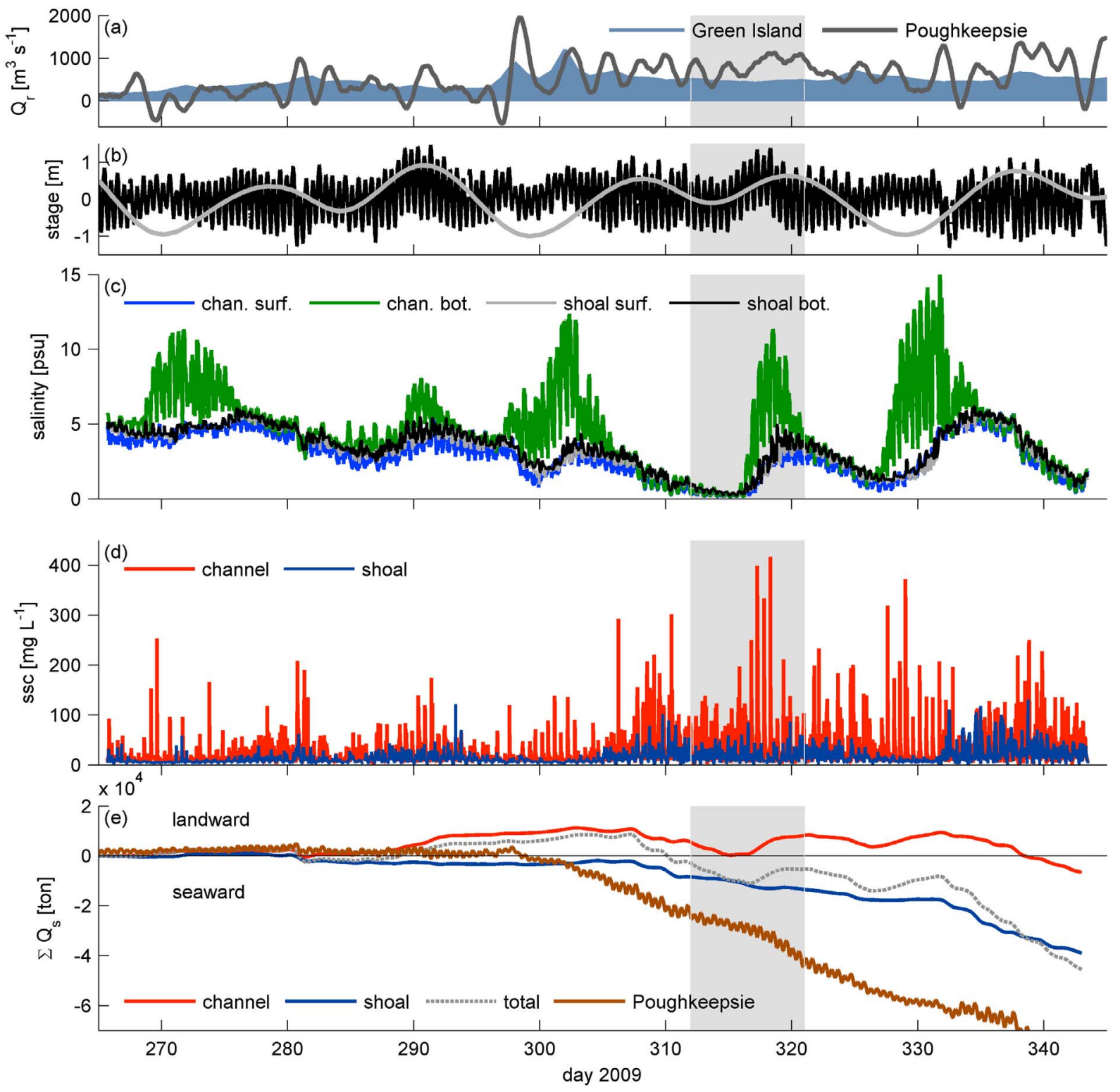

Figure 2. Time series of conditions during the observations. (a) Hudson river discharge measured at Green Island (USGS 01358000) and tidally filtered volume flux at Poughkeepsie (USGS 01372058). (b) Tidal stage measured at the Battery (NOAA 8518750) with the amplitude of the spring-neap cycle shown in gray based on a low-pass filter of the tidal harmonics. (c) Near-bottom and surface salinities at the channel and shoal stations in Haverstraw Bay. (d) Near-bottom suspended-sediment concentrations at the channel and shoal stations (both $0.35 \mathrm{mab}$ ). (e) Cumulative sediment fluxes at the channel and shoal stations based on near-bottom suspended sediment and velocity measurements, with positive values for landward flux. Also shown is the cumulative sediment flux measured at Poughkeepsie (USGS 01372058). Shaded period in all panels corresponds with spring-neap cycle shown in Figure 3.

much less than the depth average due to the strong shear in stable stratification. During spring tides, the channel was unstratified and $\partial s / \partial x$ was more uniform, and not frontal. Near-bottom velocities and SSC were more tidally symmetric during springs, and SSC was in phase with the near bottom velocity (Figure 3).

[17] The salinity fronts were less apparent at the shoal station. Some neap tides saw a rapid increase in bottom salinity that lagged the passage of the front in the channel (Figure 3), but the increase in bottom salinity due to the front, and thus the stratification, was much less. More importantly for sediment transport, the high SSC at the front in the channel was not observed on the shoal. Rather than flood tide maxima, the highest SSC on the shoal during both neap and spring tides occurred during ebbs. Any stratification created on the shoal during a neap flood tide was mixed away early in the ebb, so velocity profiles were more vertically uniform than in the channel.

[18] To summarize the time series observations, the channel-shoal and tidal asymmetries in salinity, SSC, and 

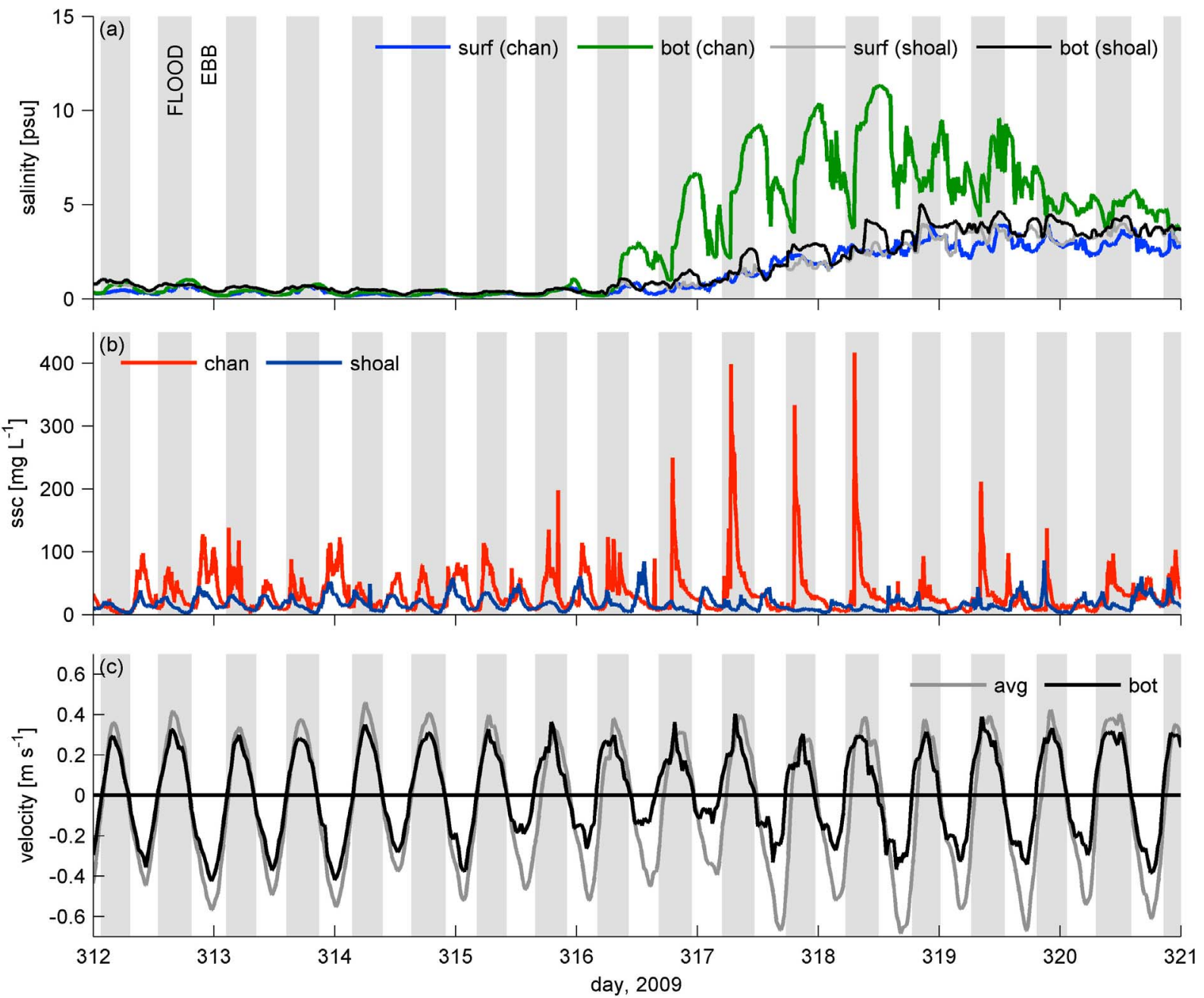

Figure 3. Observations in Haverstraw Bay over part of a spring-neap cycle. (a) Near-bottom and surface salinities at the channel and shoal stations. (b) Near-bottom suspended-sediment concentrations at the channel and shoal stations. (c) Depth-averaged and near-bottom velocities at the channel station. Shaded periods in all panels correspond with flood tides (velocity $>0$ ) in the channel.

near-bottom velocity were regular, repeatable features that depended on the spring-neap variation in the salinity intrusion. In the channel during neaps, near-bottom velocities and sediment concentrations were greatest during flood tides, with decreased near-bottom velocities and SSC during ebbs. In the channel during springs, the ebb-flood asymmetry was less pronounced and the maximum SSC were lower. On the shoal, the spring-neap variability appeared largely in the amplitude of the velocity and SSC rather than in ebb-flood asymmetries. Maximum near-bottom velocities and SSC occurred during ebbs, with greater amplitudes during spring tides.

[19] Based on the observed near-bottom velocities and SSC, we estimated the cumulative sediment fluxes in Haverstraw Bay. We assumed that conditions at the instruments were laterally representative, and used the channel $(\sim 1 \mathrm{~km})$ and shoal $(\sim 3 \mathrm{~km})$ widths to extrapolate from the point observations. The vertical structure of SSC was assumed to follow a Rouse profile, using a sediment settling velocity of $0.6 \mathrm{~mm} \mathrm{~s}^{-1}$. During stratified periods in the channel, the vertical structure of suspended sediment was likely modified from the Rouse assumption due to suppression of turbulence at the pycnocline, resulting in lower SSC in the surface layer. However, the depth-integrated sediment fluxes were dominated by the near-bed SSC, so the results were relatively insensitive to the assumed vertical structure. The acoustic backscatter sensors measured vertical profiles every $30 \mathrm{~min}$, but this interval was inadequate to resolve the bottom salinity fronts and associated sediment fluxes that passed by in 10 to $30 \mathrm{~min}$. The sediment flux calculations from observations also assumed that fluxes were laterally uniform near each sensor, a necessary simplification that could be violated during periods with lateral fronts.

[20] Uncertainties in the lateral and vertical structures of SSC change the magnitude of the calculated fluxes, but basic differences between channel and shoal in the direction of sediment flux appear to be robust (Figure 2e). Sediment fluxes in the channel were generally up-estuary during neaps and down-estuary during springs, with the net transport over the observations slightly seaward. On the shoals, fluxes were strongly seaward, particularly during spring tides. The total seaward sediment flux measured at Poughkeepsie during the 

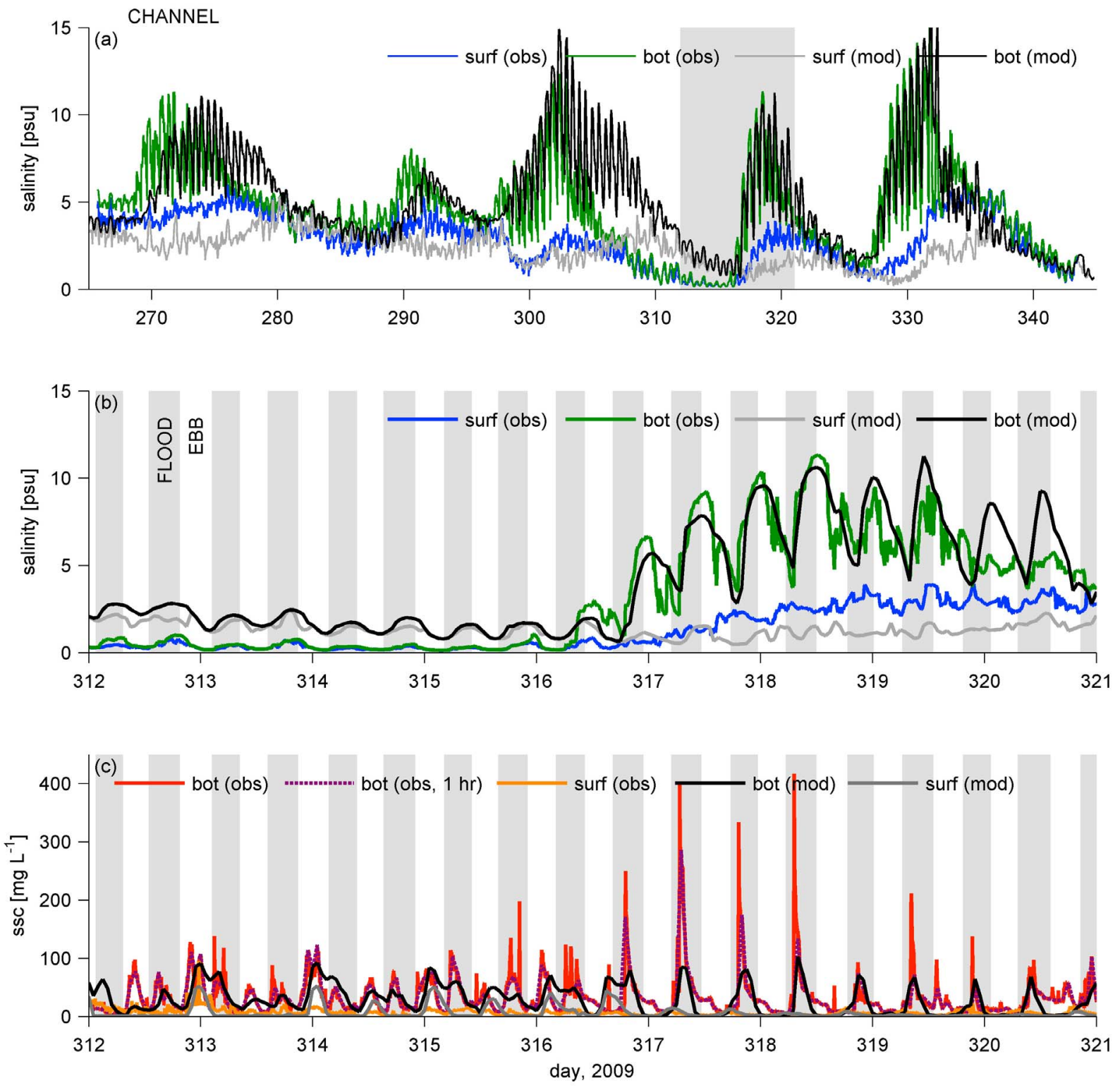

Figure 4. Comparison between model and observations at the channel station in Haverstraw Bay. (a) Near-bottom and surface salinities over the full observation period. (b) Near-bottom and surface salinities during a transition from spring to neap tides, as in Figure 3. (c) Near-bottom and surface suspended-sediment concentrations. The observation sampling interval was $5 \mathrm{~min}$, but the purple dashed line has been down-sampled to the same $1 \mathrm{~h}$ interval as the model output. Shaded region in Figure 4a shows the focus period in Figures $4 b$ and $4 c$; shaded regions in Figures $4 b$ and $4 c$ correspond with flood tides (velocity $>0$ ).

observations exceeded the calculated fluxes in Haverstraw Bay (Figure 2e), but sediment deposition and storage between the two locations could account for the differences [Wall et al., 2008].

[21] Two prominent features from the observations in Haverstraw Bay were high SSC at salinity fronts in the channel during neap, flood tides, and the lateral segregation of net sediment flux, with landward transport in the channel during neaps and seaward on the shoals during springs. We compare these observations to model results of the full estuary to evaluate whether these are unique, local features or if they are more generally characteristic of sediment transport in the Hudson.

\subsection{Model Results}

[22] An earlier version of the model was evaluated against observed salinities and velocities over several months in 2004 [Warner et al., 2005, 2008]. The observations from this study were more limited in number and extent, but comparisons with the model results have found generally good agreement (Figures 4 and 5). At spring-neap time scales, the model reproduced the variation in salinity and stratification in the channel that corresponds with variability 

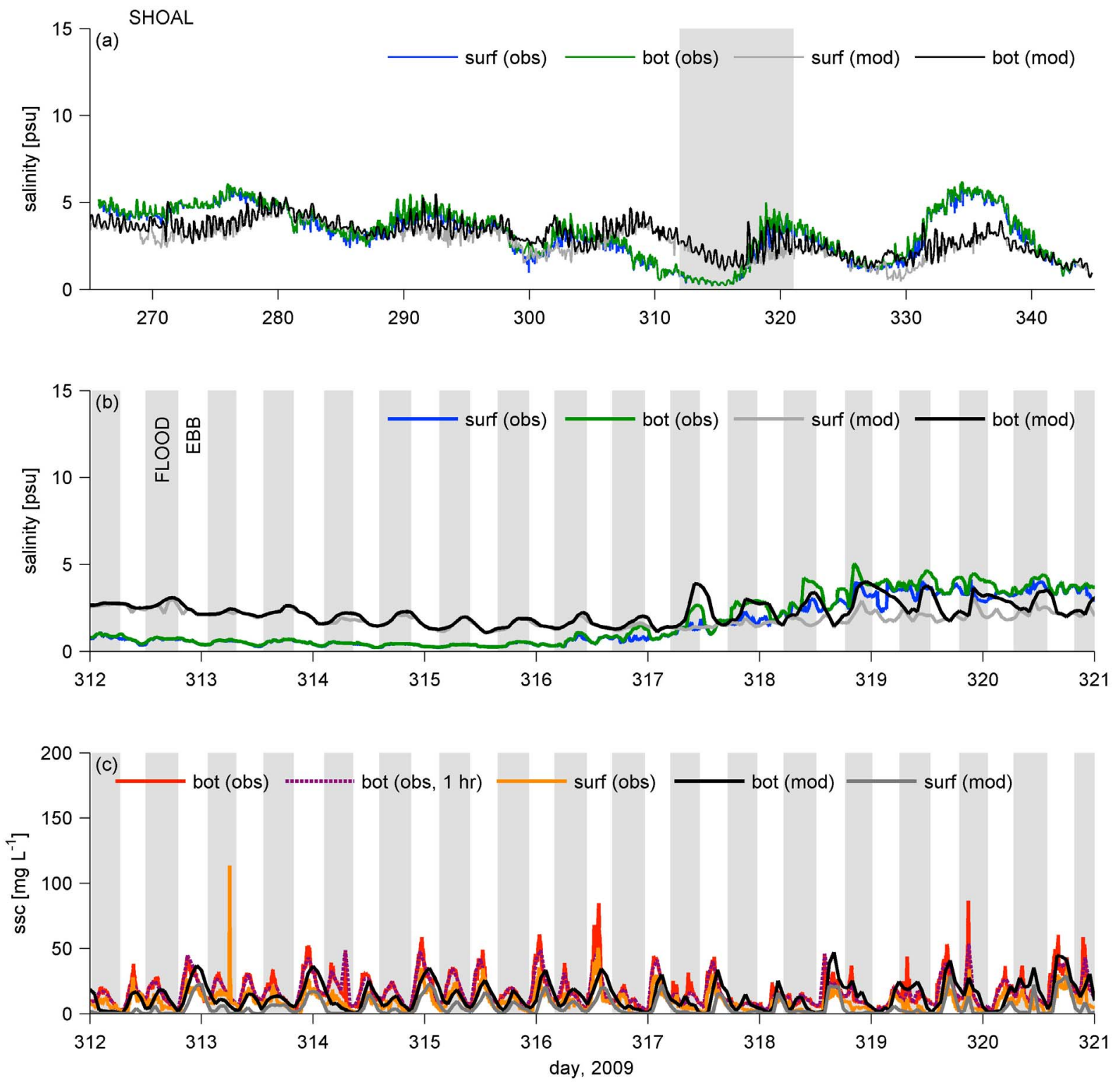

Figure 5. Comparison between model and observations at the shoal station in Haverstraw Bay. (a) Nearbottom and surface salinities over the full observation period. (b) Near-bottom and surface salinities during a transition from spring to neap tides, as in Figures 3 and 4. (c) Near-bottom and surface suspendedsediment concentrations. The observation sampling interval was $5 \mathrm{~min}$, but the purple dashed line has been down-sampled to the same $1 \mathrm{~h}$ interval as the model output. Shaded region in Figure 5a shows the focus period in Figures $5 \mathrm{~b}$ and $5 \mathrm{c}$; shaded regions in Figures $5 \mathrm{~b}$ and $5 \mathrm{c}$ correspond with flood tides (velocity $>0$ ).

in tidal mixing and the salinity intrusion length (Figure 4a). At tidal time scales, the advancement of the salinity intrusion in the channel during neap tides was as a bottom front as noted in the observations, seen in the time series as rapid increases in near bottom salinity during flood tides (Figure 4b). In both the observations and model, stratification on the shoals was weak during neap tides and eliminated during springs (Figure 5).

[23] SSC both in the channel $\left(\sim 50\right.$ to $\left.100 \mathrm{mg} \mathrm{L}^{-1}\right)$ and on the shoals $\left(\sim 10\right.$ to $\left.40 \mathrm{mg} \mathrm{L}^{-1}\right)$ compare well during spring tides with the observations, as well as on the shoals during neaps (Figures $4 \mathrm{c}$ and $5 \mathrm{c}$ ). In the channel during neap tides, sediment concentrations were tidally asymmetric as observed, with greater SSC during flood tides, but the SSC maxima associated with the bottom salinity fronts were less in the model $\left(\sim 100 \mathrm{mg} \mathrm{L}^{-1}\right)$ than in the observations ( 200-400 $\mathrm{mg} \mathrm{L}^{-1}$ ). Similarly, horizontal salinity gradients at fronts in the model were locally enhanced, but the maximum $\partial s / \partial x$ in the model $\left(\sim 10 \mathrm{psu} \mathrm{km}^{-1}\right)$ was less than calculated from observations $\left(\sim 80 \mathrm{psu} \mathrm{km}^{-1}\right)$. The alongestuary grid discretization was 50 to $100 \mathrm{~m}$, similar to the length scales of the fronts in the observations, so numerical diffusion may limit the ability of the model to resolve fully the sharp gradients that were observed.

[24] Despite some limitations, the dominant physical processes identified in the observations do appear to be 

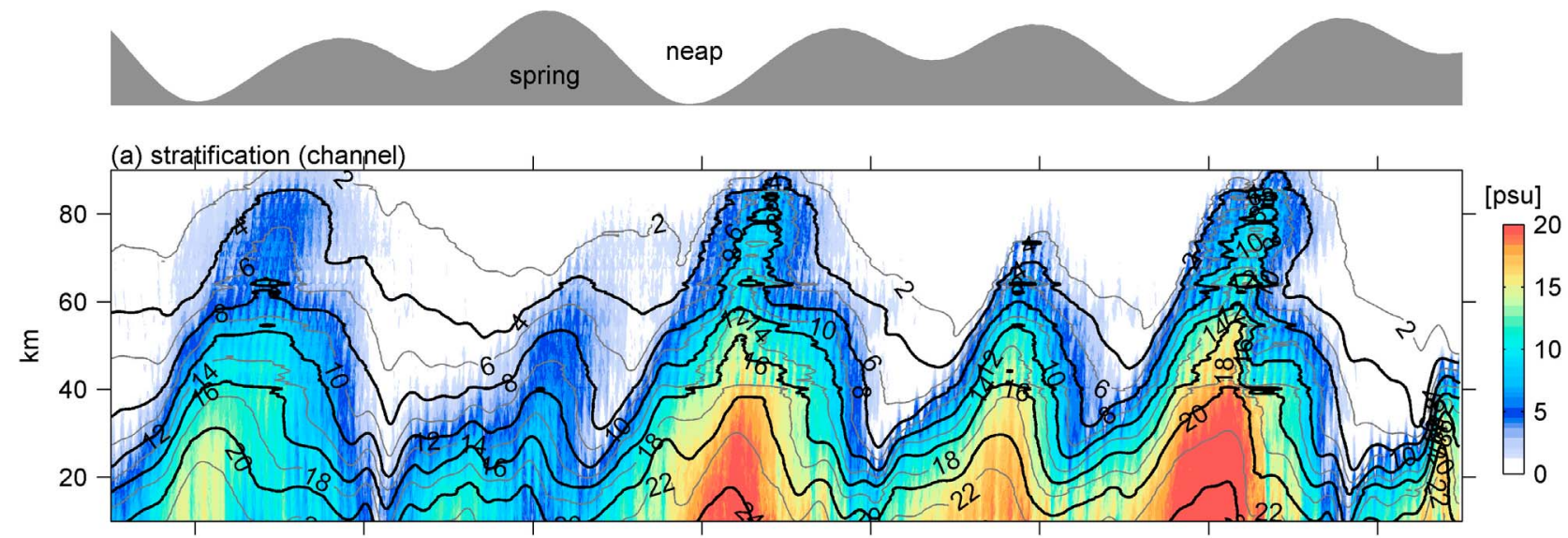

(b) $\partial s / \partial x_{b}$ (channel)


Figure 6. Time series of along-channel sections from model results. (a) Stratification in the channel, defined as the difference between surface and bottom salinity. (b) Tidally averaged along-channel salinity gradient, using the depth-averaged salinity. (c) Tidally averaged near-bottom along-channel velocity. Overlaid contours in Figures $6 \mathrm{a}$ and $6 \mathrm{~b}$ are of bottom salinity in the channel (every 2 psu, alternating black and gray); contours in Figure $6 \mathrm{c}$ are of stratification (top-to-bottom difference, every $3 \mathrm{psu}$ ). Trace at the top of the figure reflects spring-neap variability in tidal amplitude, as in Figure $2 b$. The triangles on the $y$-axes in this and subsequent figures mark approximate positions of persistent fronts as seen in the intensified $\partial s / \partial x$ and near-bottom velocity of Figures $6 \mathrm{~b}$ and $6 \mathrm{c}$.

reproduced in the model: neap tide salinity fronts increase stratification and SSC, and channel-shoal asymmetries in stratification and the direction of net sediment flux (shown later). To analyze the model results, we laterally distinguish between channel and shoal regions based on the mean depth at each cross-section. Grid cells deeper than the mean at a cross-section are classified as in the channel, and cells shallower than or equal to the mean depth are defined as on the shoals (Figure 1). Lateral averages of model quantities based on these definitions are used as a simplified means of quantifying the effects of lateral bathymetric gradients.
[25] The spring-neap variability in salinity and stratification observed in the channel of Haverstraw Bay (Figures 2 and 4) is consistent with the fortnightly variability in the position of the salinity intrusion in the model (Figure 6a). During neap tides, the salinity field and stratification moved up the channel and reached its maximum landward extent during the transition from neap to spring tides (e.g., day 304). As the tidal velocities increased during spring tides, the salinity intrusion was pushed seaward, typically 1 or 2 days after maximum spring tides (e.g., day 310). Similar spring-neap propagation of the salinity intrusion and 
stratification was observed in moorings along the Hudson in 2004 [Ralston et al., 2008].

[26] The spring-neap variability in the salinity intrusion corresponded with an along-estuary propagation of $\partial s / \partial x$ (Figure 6b). As the salinity intrusion moved landward, a region of elevated $\partial s / \partial x$ occurred at salinities of 5 to $15 \mathrm{psu}$. However, some of the strongest salinity gradients did not translate with the salinity intrusion but instead remained fixed at discrete locations along the estuary. At these locations, which typically corresponded with transitions in estuary width or depth, bottom salinity fronts formed around slack before flood each tidal cycle. At times, $\partial s / \partial x$ at these frontal locations was greater than the $\partial s / \partial x$ associated with the head of the salinity intrusion. The locations of the fronts were consistent over several spring-neap cycles, and the fronts were spaced roughly a tidal excursion apart $(\sim 10 \mathrm{~km})$. We have identified the frontal locations based on local maxima in time-averaged $\partial s / \partial x$, and marked them on subsequent figures.

[27] The mechanisms of frontal formation are not the focus here, but we briefly describe the process because the fronts directly impact sediment transport. Downstream from constrictions during ebb tides, the surface layer above the pycnocline spreads and thins as it expands laterally. The bottom layer slows downstream of the constriction, initiating a convergence of the horizontal salinity gradient $((\partial u / \partial x)$ $(\partial s / \partial x))$. The convergence results in a local intensification of $\partial s / \partial x$, which enhances the landward baroclinic pressure gradient, thus amplifying the convergence in near-bottom velocity. The positive feedback between velocity convergence and baroclinicity rapidly amplifies the strength of the near-bottom front. This baroclinic convergence appears to be the dominant mechanism for frontal formation in the Hudson, with additional details to be presented in W. R. Geyer et al. (manuscript in preparation, 2012). Here we focus on the effects of the bathymetric bottom salinity fronts on sediment transport.

[28] At many of the locations with bottom salinity fronts and locally intensified $\partial s / \partial x$, the tidally averaged nearbottom velocities were enhanced landward (Figure 6c). The advancing edge of the salinity intrusion marked a transition between landward residual velocities and seaward nearbottom flow in the fresh region upstream, particularly during the higher discharge period late in the study. At the locations with persistently high $\partial s / \partial x$, the near-bottom residual velocities remained strongly landward after the head of the salinity intrusion had moved farther up-estuary (horizontal banding in Figure 6c). In addition to the spring-neap pulsing of the salinity intrusion and near-bottom velocities, meteorological time-scale fluctuations were notable in near bottom velocity (vertical banding in Figure 6c). The currents due to barotropic exchange at the coast extended over the entire estuary and were often greater in magnitude than (and at times the opposite sign of) the mean flow due to the river discharge.

[29] SSC in the model varied along the estuary, between the channel and shoals, and temporally with the spring-neap cycle (Figure 7). Some of the highest concentrations occurred during spring tides in the lower ETM $(\sim 18 \mathrm{~km})$, particularly on the shoals. This is consistent with lateral patterns of SSC observed in the lower ETM [Geyer et al., 2001], although maximum concentrations in the model ( $\sim 300 \mathrm{mg} \mathrm{L}^{-1}$ ) were less than observed during spring freshet conditions $\left(\sim 1000 \mathrm{mg} \mathrm{L^{-1 }}\right)$ [Traykovski et al., 2004]. The spatial and temporal distributions of SSC largely corresponded with the bottom stress (Figure 7a). Elevated SSC in the narrow lower estuary $(<\sim 35 \mathrm{~km})$ corresponded with a zone of high tidal stresses, with similarly high stresses and SSC in the narrow Hudson Highlands region farther upstream $(>\sim 60 \mathrm{~km})$. Sediment concentrations and stresses decreased in the wide region mid-estuary (Tappan Zee and Haverstraw Bay, 40-60 km), particularly in stratified regions during neap tides.

[30] Lateral gradients in suspended sediment between channel and shoal were apparent in the model and the observations, and to characterize the differences we averaged model results temporally over the study period (Figure 8). Stratification was weaker on the shoals than in the channel, particularly on the wide shoals of Tappan Zee and Haverstraw Bay (Figure 8c). The effect of the landward estuarine circulation on mean near-bottom velocity was most apparent in the channel, while mean near-bottom velocities on the shoals were seaward (Figure 8d). Bed stresses were greater in the channel than on the shoals (Figure 8e), a lateral stress gradient that is consistent with a simplified alongestuary momentum balance between stress divergence and the barotropic pressure gradient, such that shallower depths have lower bottom stresses.

[31] For suspended sediment, gradients between channel and shoal varied along the estuary. In the lower estuary $(<\sim 35 \mathrm{~km})$, concentrations were greater on the shoals, while in much of the mid- and upper-estuary concentrations were greater in the channel (Figure 8f). Bed stresses were greater in the channel almost everywhere, but sediment concentrations also depended on the bed erodibilty (Figure $8 \mathrm{~g}$ ). In the lower estuary, fine sediment was located on the western shoals, and the channel bed was composed of coarser material with higher critical stresses for erosion. Consequently, although the bed stresses in the lower estuary channel were typically greater than the shoals, the highest SSC were on the shoals. In the upper estuary $(>60 \mathrm{~km})$, bed sediment was more laterally uniform and predominantly fine. There, lateral gradients in SSC were driven by bed stress, with higher stresses and higher SSC in the channel.

\subsection{Lateral Partitioning of Sediment Flux}

[32] The along-estuary sediment flux depended both on the velocity (Figure 6) and SSC distributions (Figure 7). In the channel, velocities were landward within the salinity intrusion and seaward in the tidal freshwater region. In contrast on the shoals, tidally averaged near-bottom velocities were often seaward (Figure 8d). The lateral gradient in residual velocity, particularly in the lower estuary, corresponded with a lateral segregation of the along-estuary sediment flux, with average fluxes landward in the channel and seaward on the shoals (Figure $8 \mathrm{~h}$ ). This distinct lateral segregation was observed in partially stratified estuaries by Nichols and Poor [1967] and Nichols [1972], but subsequently has received surprisingly little attention in the literature.

[33] Considering the time dependence of the spring-neap cycle, the sediment fluxes in the channel followed the nearbottom residual velocities, with enhanced up-estuary flux as the salinity intrusion moved landward during neaps (Figure 9). In unstratified regions with low salinity, sediment 


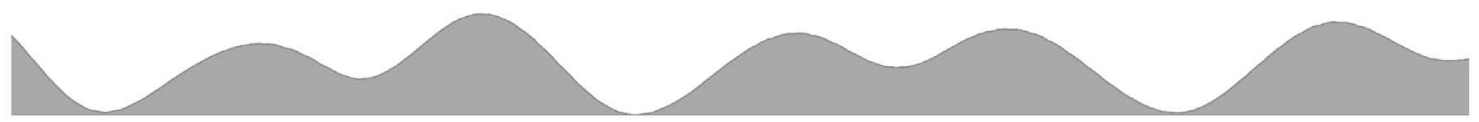

(a) channel: $\left\langle\left|\tau_{b}\right|>\right.$


Figure 7. Time series of along-estuary sections from model results. (a) Tidally averaged magnitude of bed stresses in the channel. (b) Tidally averaged near-bed suspended-sediment concentrations in the channel. (c) Tidally averaged near-bed suspended-sediment concentrations on the shoals. Overlaid contours are of bottom salinity in the channel (every 2 psu, alternating black and gray). Trace at the top of the figure reflects spring-neap variability in tidal amplitude, as in Figure 2b.

fluxes in the channel were down-estuary, particularly after the increase in river discharge around day 300. On the shoals, the strongest down-estuary fluxes occurred in the lower estuary during spring tides, and only for brief periods during neap tides were sediment fluxes landward on the shoals in the lower estuary. Both in the channel and on the shoals, the variability in sediment flux due to the meteorological forcing at the seaward boundary was pronounced, apparent in the vertical banding of roughly 1-day duration.

[34] The definitions of channel and shoal for spatial averaging of model results were arbitrary (based on mean cross-sectional depth), but the basic concept of a lateral partitioning of sediment flux is insensitive to the definition.
Averaging in time rather than space, maps of sediment flux also featured strong channel-shoal gradients (Figure 10). The distinction was most evident in the lower estuary where the salinity intrusion was persistent (Figure 10a). Sediment transport in the channel was strongly landward while transport on the western shoals was seaward. The partitioned fluxes in the lower estuary were large but nearly balanced, such that the cross-sectional net flux was much less than would be measured in the channel or on the shoals alone. In the upper estuary, the bathymetry was more varied, with the channel transitioning from the eastern to the western shore near the constriction at Croton Point (Figure 10b). The sediment fluxes in the upper estuary were less than in the 


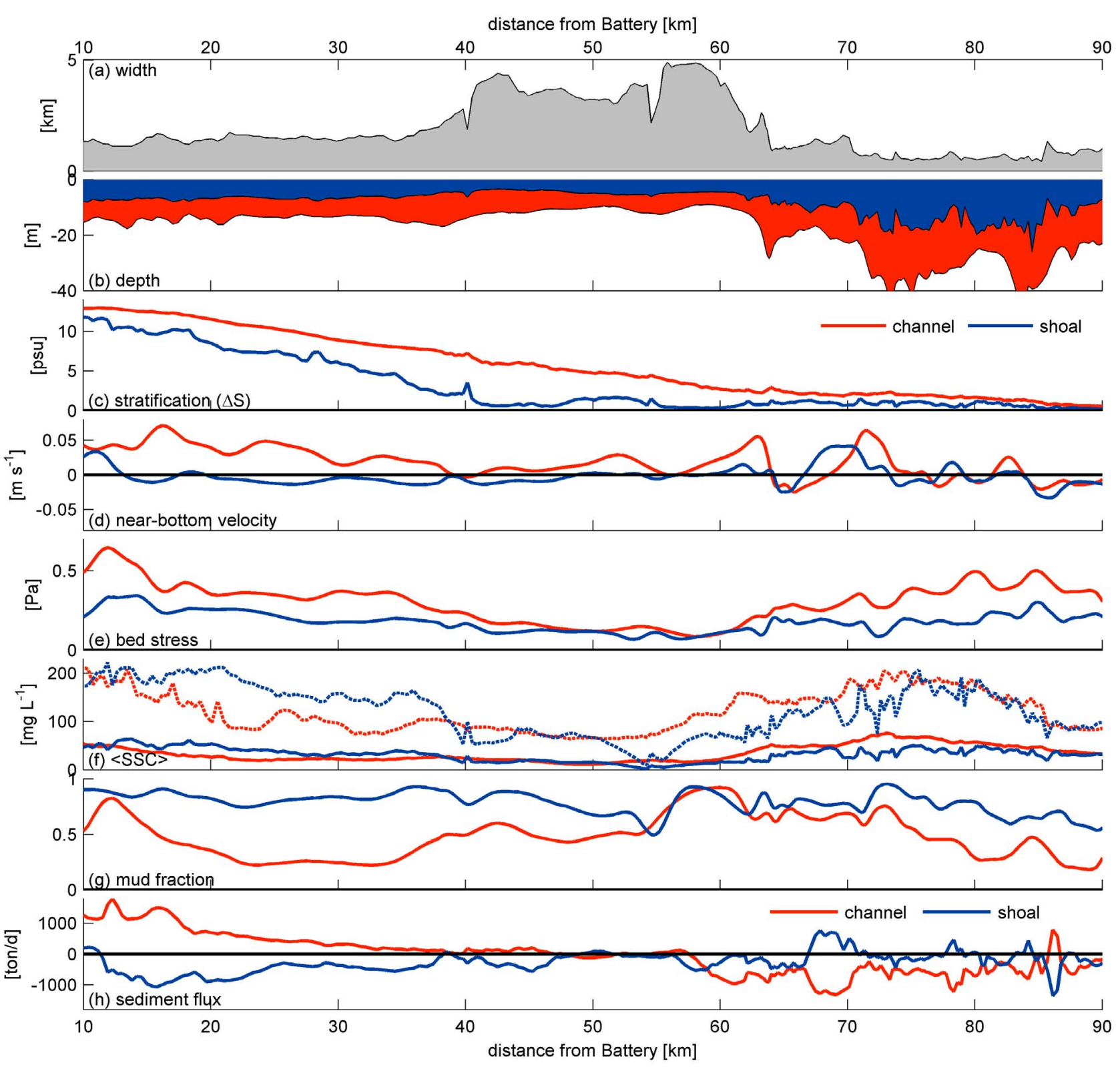

Figure 8. Temporal averages over the 3 month simulation from model results as a function of distance along the estuary. (a) Width of the estuary. (b) Average depth of the channel (red) and shoals (blue). (c) Average surface-to-bottom stratification of the channel (red) and shoals (blue). (d) Average near-bed along-estuary velocity. (e) Average bed stress magnitude. (f) Average and maximum (dashed) suspended-sediment concentrations. ( $\mathrm{g}$ ) Average fraction of the bed material that is mud (sediment class \#3 in Table 1). (h) Average sediment flux in the channel (red) and on the shoals (blue).

lower estuary, but the transport was also laterally segregated. The average landward transport in the channel decreased with distance up-estuary, corresponding with the decreasing frequency and duration of the salinity intrusion reaching a given location.

[35] Time series of net sediment flux from the model in Haverstraw Bay (Figure 10c) find similar cumulative sediment fluxes as calculated from observations (Figure 2). Upestuary fluxes occurred in the channel during neap tides, as SSC was greater during floods and mean near-bottom velocities were landward. Spring tide fluxes in the channel were more balanced between flood and ebb. During the large spring tides and high river discharge at the end of the study, fluxes in the channel were seaward because the salinity intrusion was seaward of the measurement location. On the shoals, the down-estuary fluxes occurred predominantly during spring tides, when tidal velocities and SSC were greater.

\subsection{Sediment Deposition and Erosion}

[36] In addition to the lateral gradients in suspended-sediment concentration and flux, the channel-shoal asymmetries in stratification and bed stress led to lateral gradients in bed sediment erosion and deposition on spring-neap time scales 


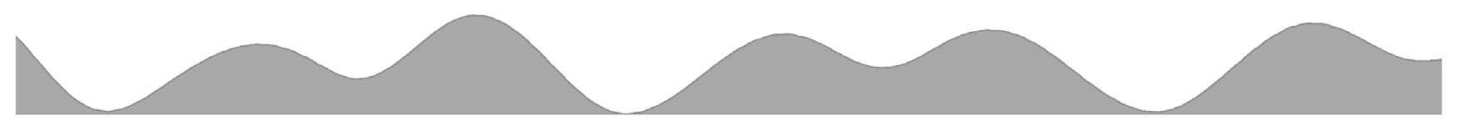

(a) channel: $Q_{\text {sed }}$

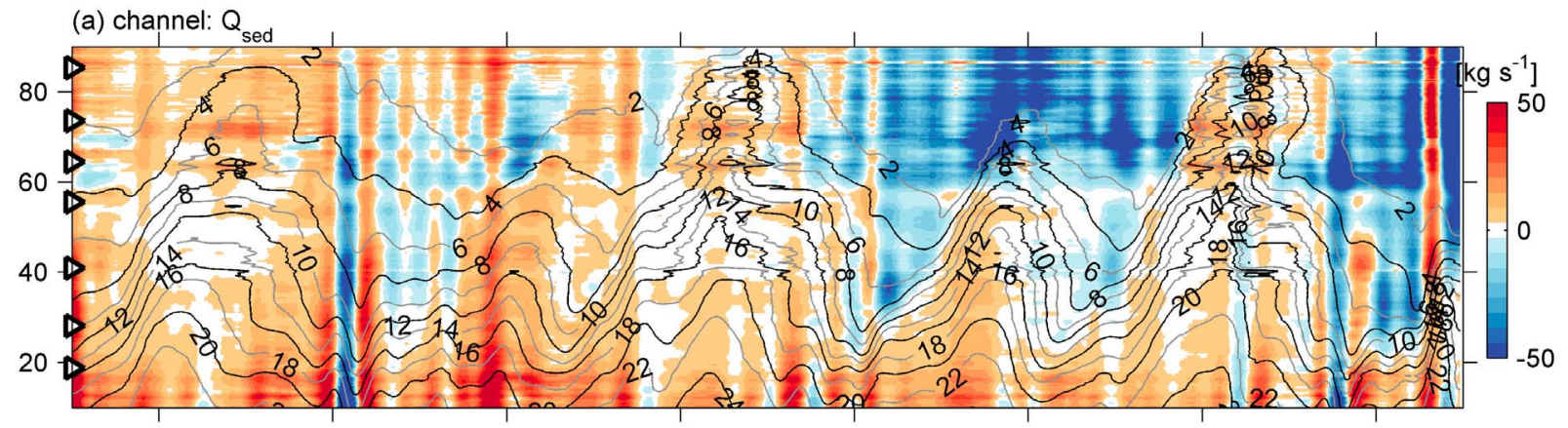

(b) shoal: $Q_{\text {sed }}$

distance from Battery $[\mathrm{km}]$

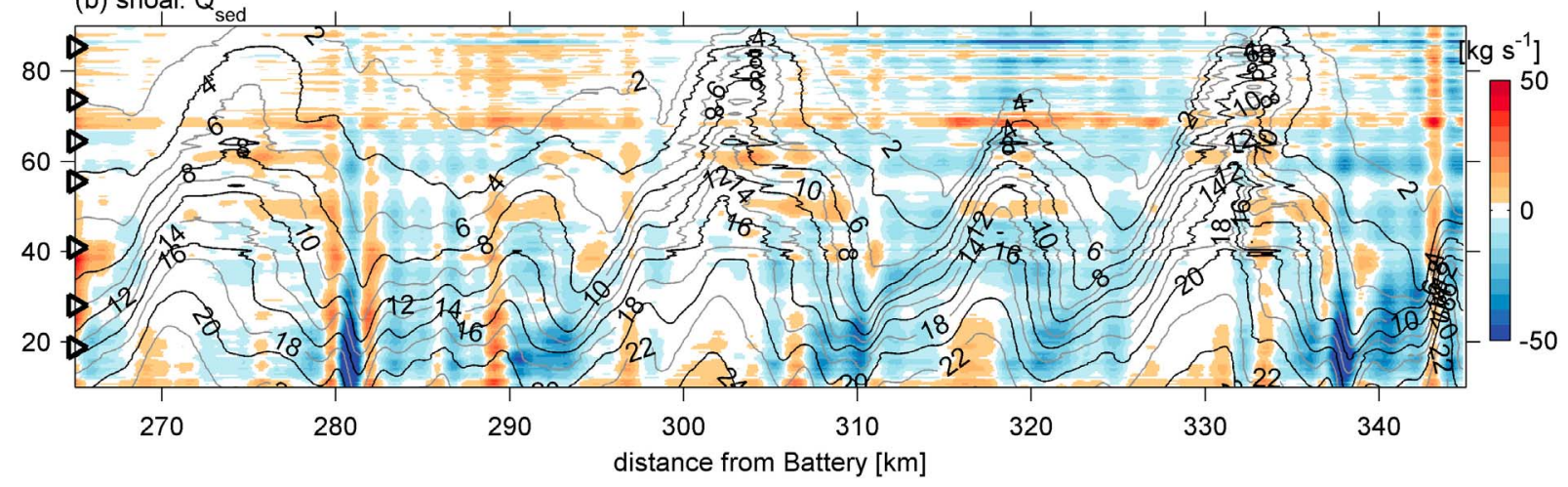

Figure 9. Time series of suspended sediment transport $\left(Q_{\text {sed }}\right)(\mathrm{a})$ in the channel and (b) on the shoals from model results. Overlaid contours are of bottom salinity in the channel (every 2 psu, alternating black and gray). Trace at the top of the figure reflects spring-neap variability in tidal amplitude.

(Figure 11). In the channel, the bed was typically erosional immediately landward and depositional immediately seaward of the head of the salinity intrusion (Figure 11a). Sharp along-estuary gradients in stratification and stress created the discontinuities in bed sediment fluxes, with erosion in the unstratified, higher stress region landward of the salinity intrusion and deposition in the stratified, lower stress region seaward. The deposition did not extend over the entire stratified length of the estuary, but instead was confined to a narrow band at the head of the salinity intrusion. In the lower estuary, the channel was generally erosional, except after large spring tides when the salinity intrusion retreated to the lower estuary (Figure 6a).

[37] On the shoals, the erosion and deposition patterns also varied with the salinity intrusion and stratification. In the lower estuary $(<40 \mathrm{~km})$ during stratified neaps, the shoals were depositional when the adjacent channel was erosional. During spring tides in the lower estuary, both the shoals and channel tended to erode. In the wider regions of Tappan Zee and Haverstraw Bay ( 40 to $60 \mathrm{~km})$, the pattern was the opposite of the lower estuary, with erosion on the shoals during neaps and deposition during spring tides.

[38] The lateral gradients in erosion and deposition differ between the lower and upper estuary due to the relative depths of the shoals in the two regions. Sediment suspension and deposition depend on bed stress, which depends on stratification, which depends on the elevation of the shoals relative to the pycnocline. Representative cross-sections from the lower and upper estuary illustrate the influence of the pycnocline on bed sediment fluxes during spring and neap tides (Figure 12). In the lower estuary during neaps, the pycnocline was elevated and stratification extended over the entire cross-section (Figure 12a). With both the shoals and channel strongly stratified, bottom stresses in the channel were greater than on the shoals. Consequently during neaps, sediment in the lower estuary eroded from the channel and deposited on the shoals, consistent with a flux from higher to lower stress. During spring tides in the lower estuary, stratification was reduced and stresses increased over the entire cross-section (Figure 12b). Sediment resuspension in the channel was limited by the lack of erodible bottom sediment (Figure 1), but SSC increased on the shoals as sediment that deposited during previous neap tides was remobilized.

[39] In wider regions, the redistribution of bed sediment had the opposite spring-neap pattern of erosion and deposition. During neaps, the channel was stratified but the shoals were not because the pycnocline was below the shoals (Figure 12c). As a result, stresses on the shoals during neaps were greater than in the channel, and sediment eroded from the shoals and deposited in the channel. During spring tides, both channel and shoals were unstratified, and stresses were greater in the channel due to the greater depth, the channel was erosional, and the shoals were depositional (Figure 12d). The channel of upper Haverstraw Bay was an exception to 


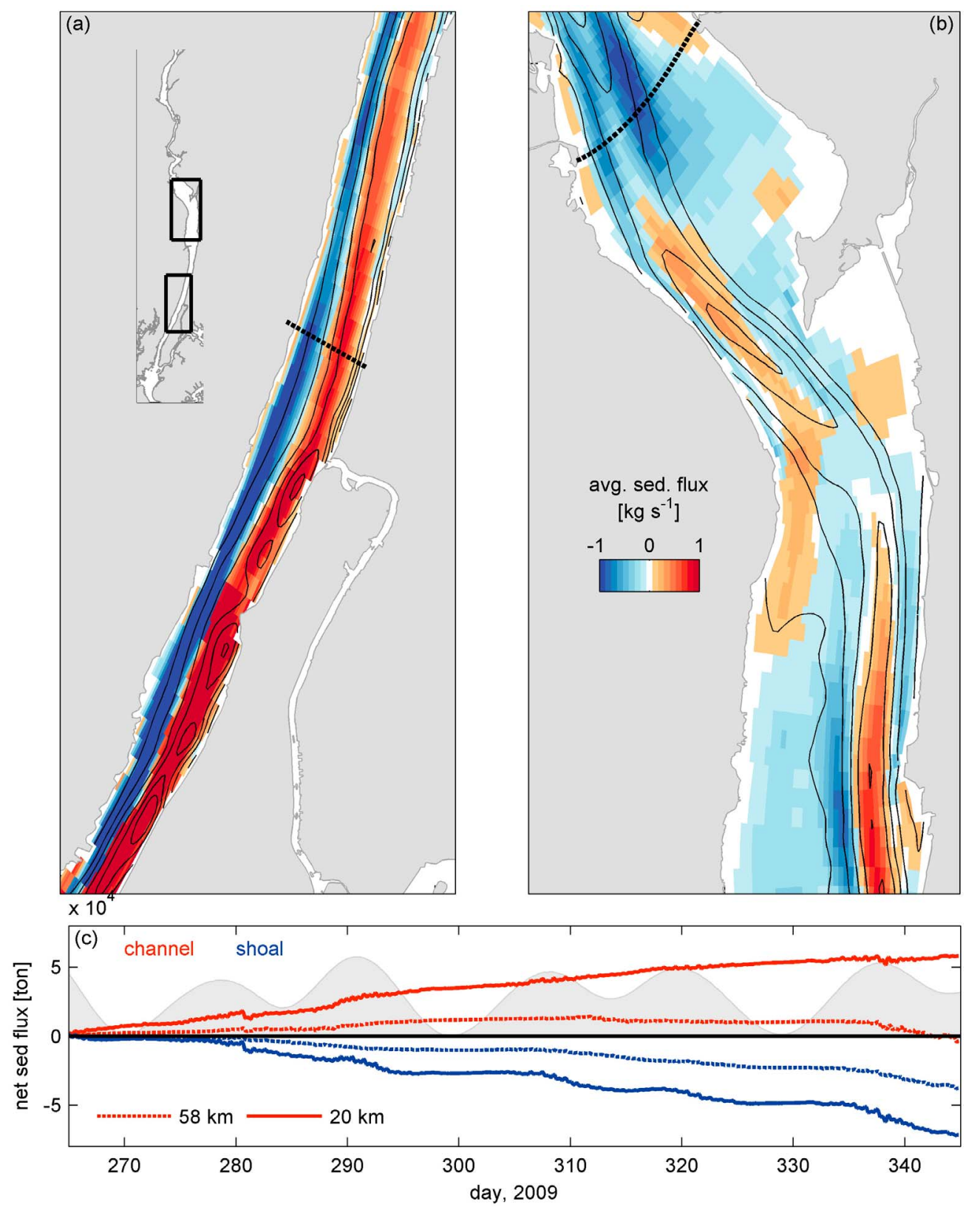

Figure 10. Maps of average sediment flux over the 3 month simulation from the model results, in (a) the lower ETM and (b) Tappan Zee and Haverstraw Bay. Red colors indicate up-estuary sediment flux and blues are down-estuary flux. (c) Time series of sediment flux from the model in the channel (red) and on the shoal (blue) extracted from locations in the lower ETM $(\sim 20 \mathrm{~km}$, solid lines) and Haverstraw Bay ( $\sim 58 \mathrm{~km}$, dashed lines). Shading indicates spring-neap variability in tidal amplitude. Dashed lines on maps show locations of cross-sections shown in Figure 12.

the pattern of erosion during spring tides, and instead was almost always depositional (Figure 11a). This region is immediately seaward of a sharp expansion and decrease in bed stress (Figure 7a), such that sediment eroded from the channel up-estuary deposited seaward of the expansion. High rates of deposition in the channel of Haverstraw are consistent with observed bed composition and with the frequent dredging for navigation [Nitsche et al., 2010].

[40] To evaluate the role of lateral gradients in stratification and stress more broadly, we plot the ratio of the tidally averaged bed stress on the shoals to that in the channel, along with the average stratification in each region ( $2 \mathrm{psu}$ top-to-bottom contour, Figure 11c). The tidally averaged elevation of the pycnocline in the channel is shown relative to the elevation of the shoals, with the pycnocline defined based on the maximum $\partial s / \partial z$ (Figure 11d, darker colors for the pycnocline below the shoals). Where the pycnocline was well below the shoals, the channel was stratified but the shoals were not, bed stresses were greater on the shoals, and the shoals were erosional while the channel was depositional (e.g., 40-60 km during neap-to-spring transitions). Where the pycnocline was well above the shoals, stresses were 

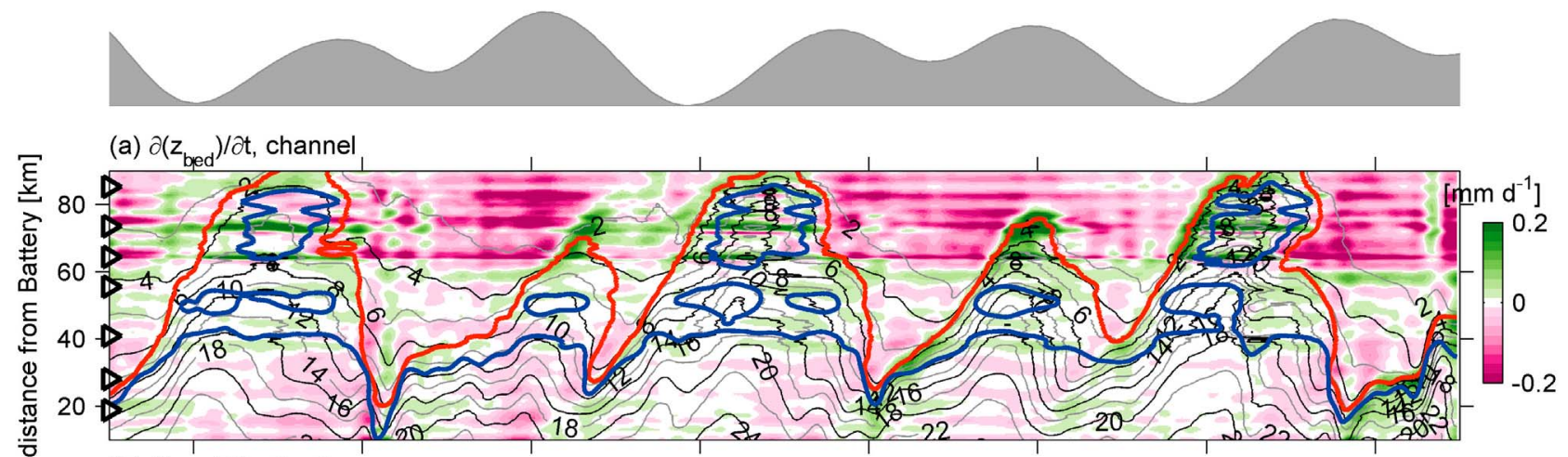
(b) $\partial\left(z_{\text {hed }}\right) / \partial t$, shoal

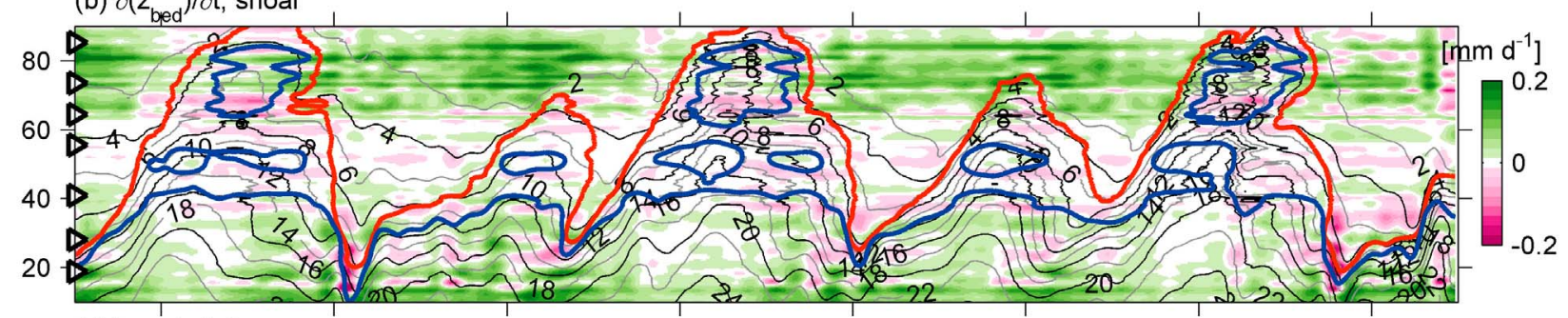

(c) $\log _{10}\left(\tau_{\mathrm{s}} / \tau_{\mathrm{c}}\right)$
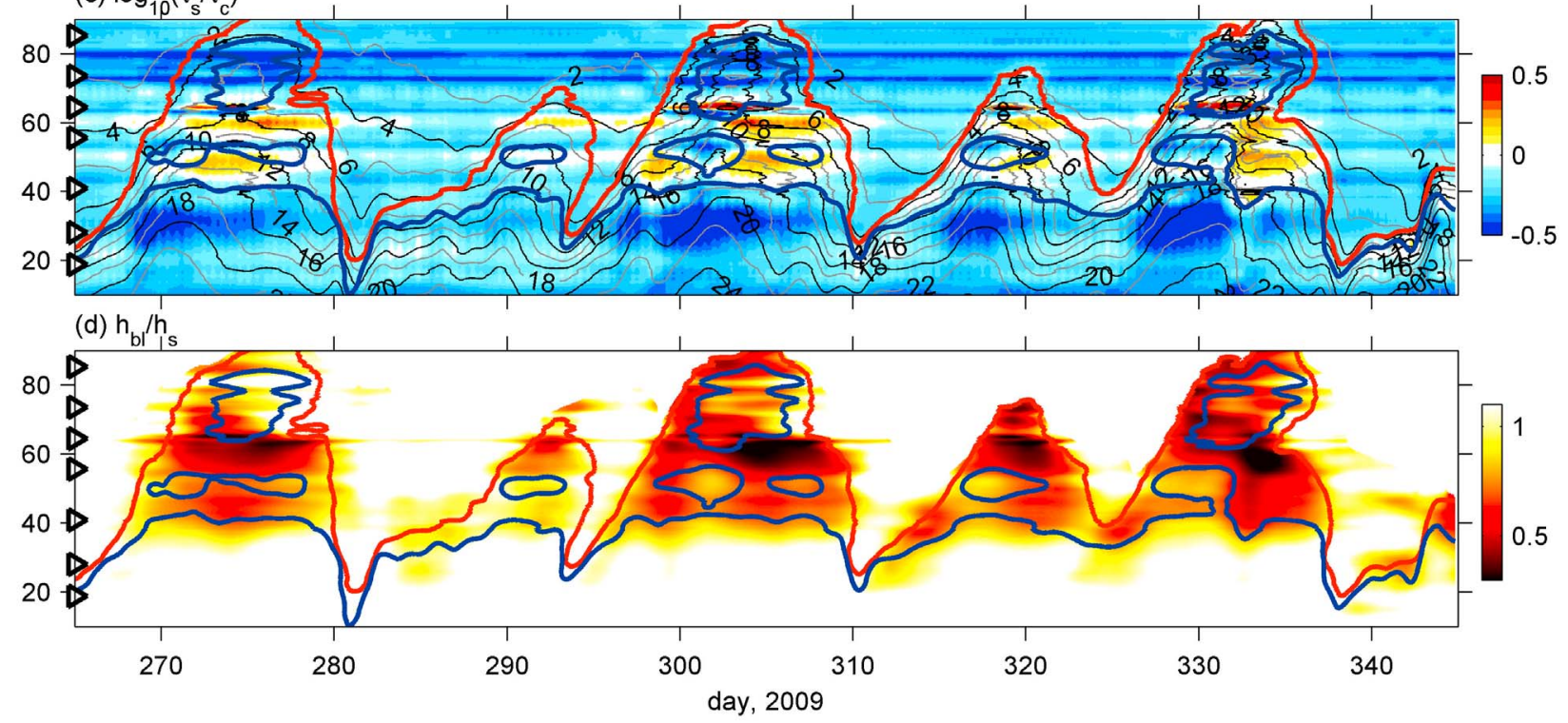

Figure 11. Time series of erosion, deposition, and differences in stress and stratification between channel and shoal from the model results. (a) Rate of change of bed elevation in the channel, with positive values for net deposition and negative values for erosion. Bottom salinity contours are shown (every 2 psu, alternating gray and black) along with contours of stratification ( 2 psu surface-to-bottom) for the channel (red) and shoals (blue). (b) Rate of change of bed elevation on the shoals. (c) Ratio of the average bed stress on the shoals to the average stress in the channel. (d) Ratio of the elevation of the pycnocline above the channel bed (defined based on the maximum in $\partial s / \partial z$ ) to the average elevation of the bed on the shoals above the channel.

greater in the channel and it was erosional while the shoals were depositional (e.g., 10-40 km during neap tides).

\subsection{Frontal Sediment Trapping}

[41] Bottom salinity fronts at multiple locations along the estuary were prominent in the model as intensified $\partial s / \partial x$ and enhanced landward near-bottom velocities (Figure 6). The fronts were associated with spatial gradients in stratification and bottom stress, but the effects of fronts on SSC were not as apparent in time series (Figures 7 and 9) or long-term averages (Figure 8). We now examine the sediment convergence and spatial gradients in resuspension and deposition in the model associated with salinity fronts in the upper estuary near the observations and in the lower ETM.

[42] In the upper estuary, a bottom salinity front regularly formed during neap tides near the constriction at Croton Point (Figure 13). Instantaneous model fields are shown for bottom salinity, bed stress, SSC, and velocity at slack tide 

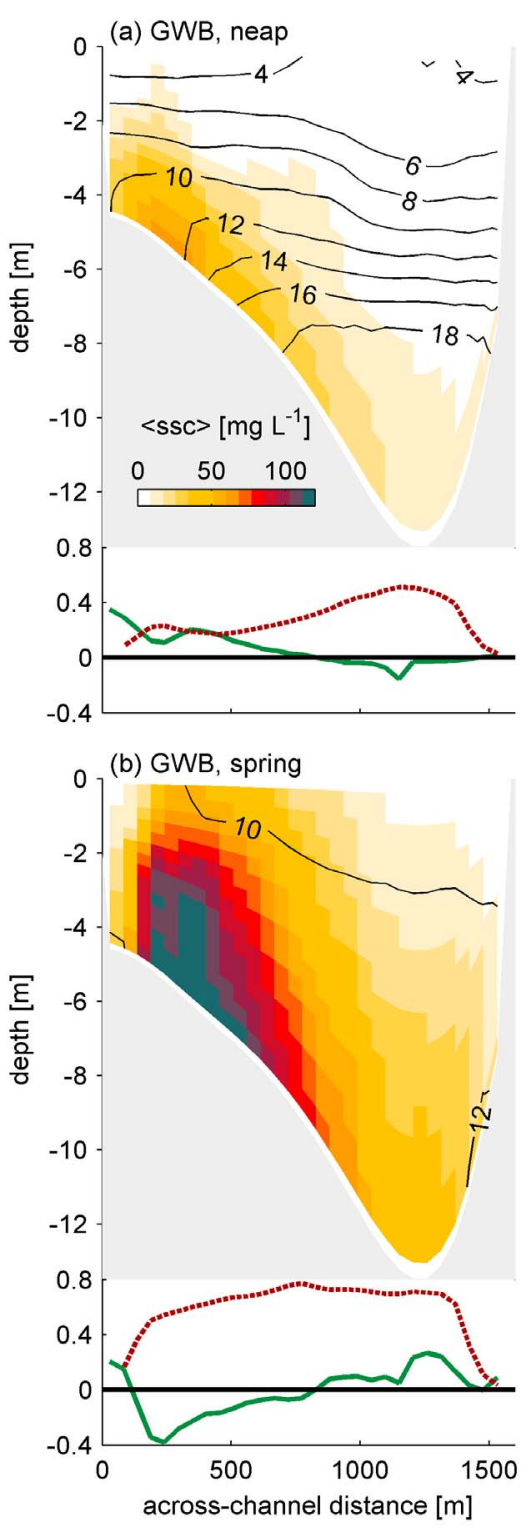

(c) Haverstraw, neap

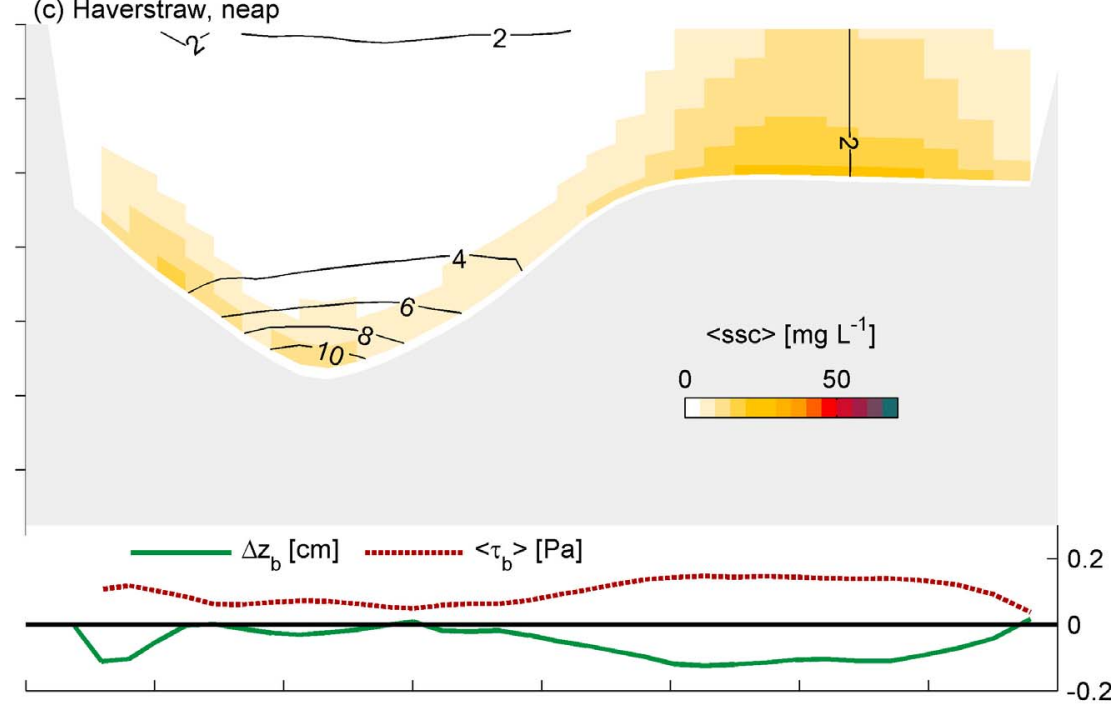

(d) Haverstraw, spring

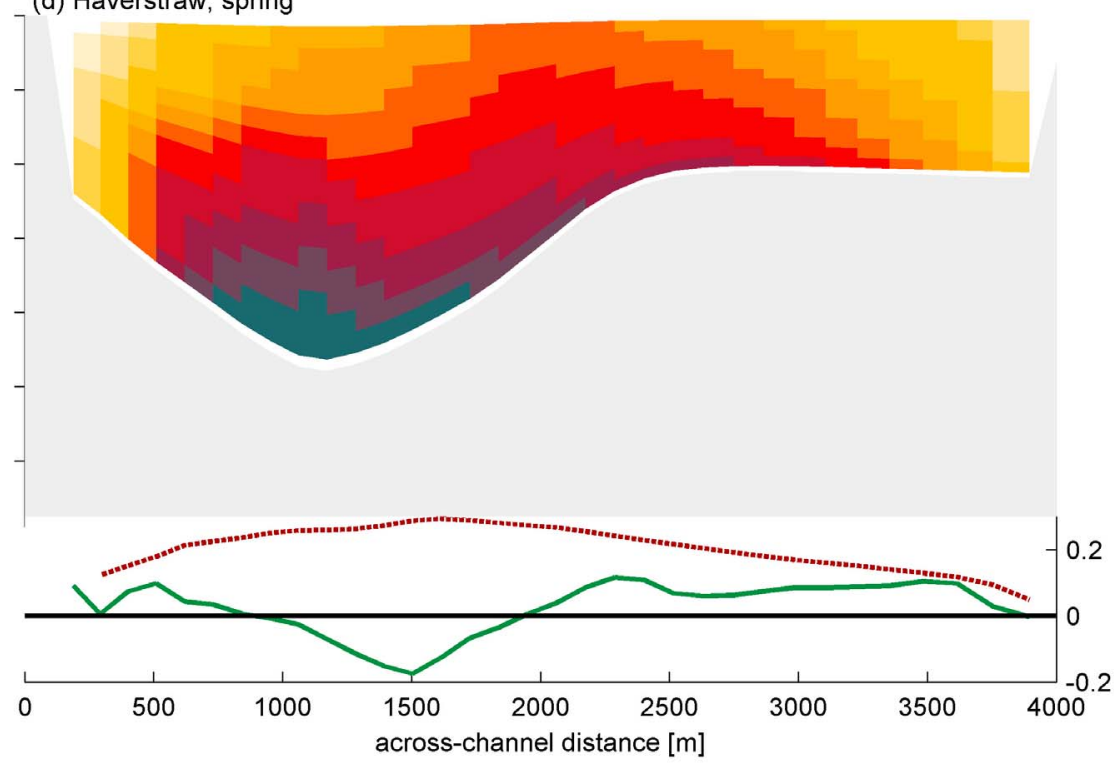

Figure 12. Cross-sections of tidally averaged conditions in (a, b) the lower ETM and (c, d) Haverstraw Bay. Locations of the cross-sections are marked in Figure 10. Figures 12a and 12c were from a neap tide (day 333) and Figures 12b and 12d were from a spring tide (day 337). Color contours are of tidally averaged suspended-sediment concentration (note the different concentration ranges between the two locations), and black contour lines are for tidally averaged salinity (every 2 psu). Panels below each cross-section show the change in bed elevation (green) and the average bed stress magnitude during the tidal cycle (red dashed).

before flood, when the front was intensifying but before it propagated landward. The front had locally enhanced $\partial s / \partial x$ along the thalweg, but it also created strong lateral gradients in bottom salinity at the edges of the channel. Spatial gradients in stratification, both along-estuary and between channel and shoal, marked the front boundaries, and the stratified region seaward of the front had weaker bottom stresses than the landward side (Figure 13b). The suspendedsediment concentrations largely correspond with the bottom stresses (Figure 13c).

[43] A section from the channel thalweg shows a local maximum in SSC at the upstream edge of the salinity front (Figure 13e), but the plan view and lateral cross-section
(Figure 13f) show that lateral sediment convergences at the edges of the channel also generated local maxima in SSC. Near-bottom velocities were convergent at the front in the along-channel direction, but lateral convergences were strong on the channel banks, corresponding to lateral gradients in SSC. Similarly, observations of lateral circulation in Winyah Bay (SC) found that the maximum suspended sediment convergences occurred at the channel banks rather than in the channel or on the shoals [Kim and Voulgaris, 2008].

[44] The longitudinal and lateral convergences associated with the front led to regions of enhanced deposition, apparent in the net change in bed elevation over a tidal cycle 
(a)

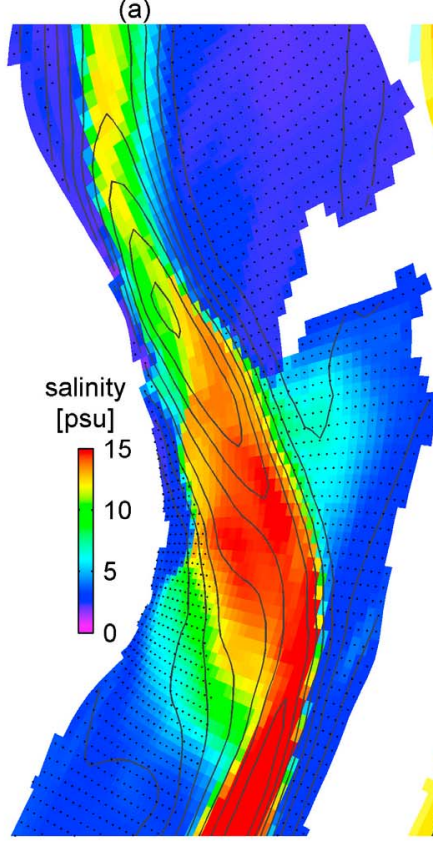

(b)

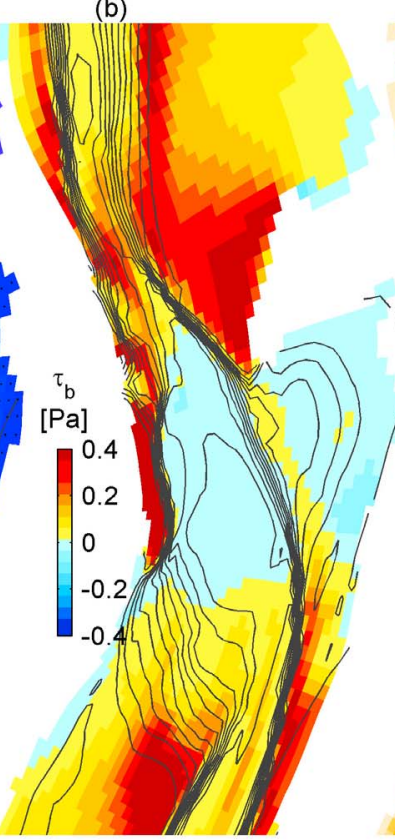

(c)

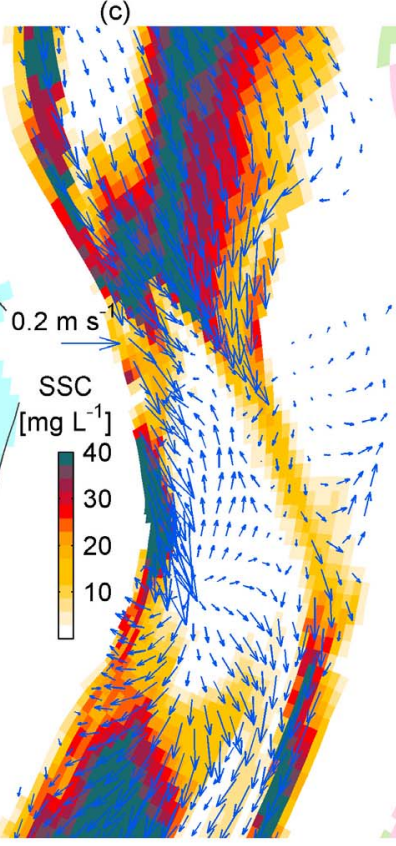

(d)

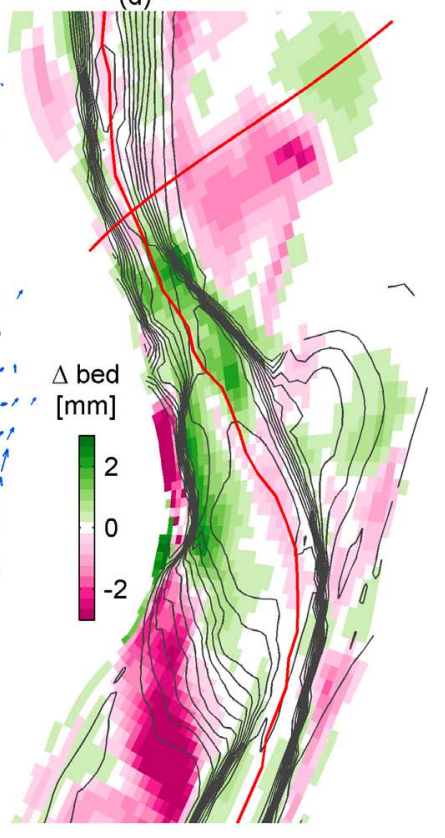

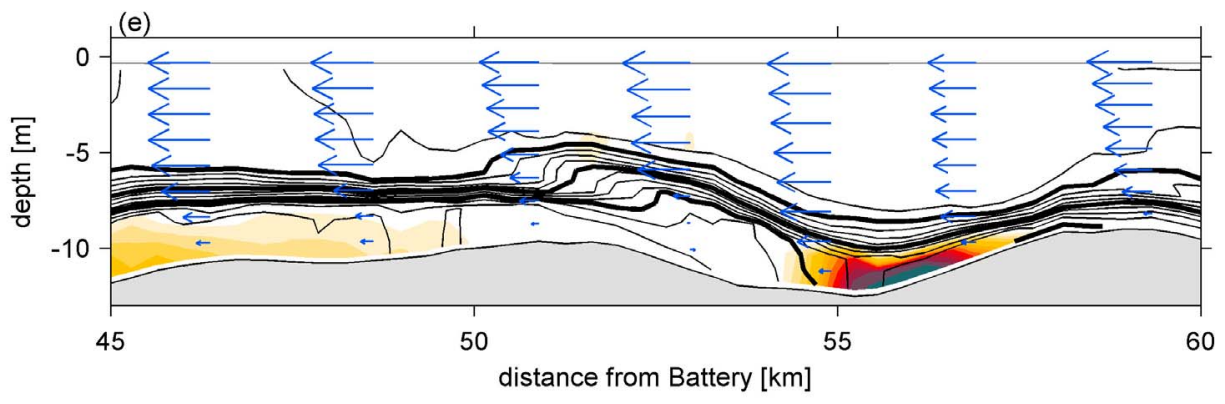

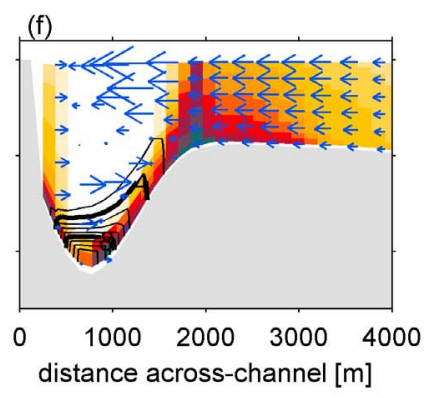

Figure 13. Sediment trapping at Croton Point front. Instantaneous model fields of (a) bottom salinity, (b) bed stress, and (c) SSC at the beginning of a flood tide (day 305), and (d) change in bed elevation over the subsequent tidal cycle. In Figure 13a contours are of bathymetry, and stippling shows grid cells that are shallower than the mean cross-sectional depth and considered "shoals." In Figures $13 \mathrm{~b}$ and 13d, contours are of bottom salinity to highlight location of the salinity front, and in Figure 13c arrows show near bottom velocities. (e) Along-channel and (f) across-channel sections of SSC, salinity (contours), and velocity (arrows). Location of along- and across-channel sections are shown as red lines in Figure 13d.

(Figure 13d). Longitudinal trapping at the landward limit of the front created deposition in the channel, but the deposition rates at the lateral fronts on the eastern and western banks were similarly high. The deposition on the banks occurred at locations deeper than the mean cross-sectional depth, and thus were considered part of the channel in the lateral averaging of the previous section; the adjacent shoal regions were erosional during this tide. The front is generated by the alongestuary change in width at Croton Point, but it leads to lateral gradients in stratification, stress and near-bottom velocity that promote deposition on the channel banks. Neap conditions when the salinity intrusion has reached the upper estuary are shown here, and much of the sediment that was trapped and deposited at the front eroded during subsequent spring tides.

[45] In the lower ETM near the George Washington Bridge, lateral salinity gradients also were prominent in sediment trapping and deposition (Figure 14). The most pronounced front was associated with the constriction and hole at the bridge, but additional, weaker fronts occurred at constrictions landward and seaward. High SSC associated with bottom salinity fronts have been previously been observed at this location [Traykovski et al., 2004]. The time shown is a slack before flood, during a transition from spring to neap tides when the salinity intrusion was near its seaward limit and fronts in the lower estuary were most intense. In this region, the channel is near the eastern shore and the fronts form at slight perturbations in the shoreline, extending seaward toward the western shoals. The bottom salinity fronts (Figure 14a) corresponded with lateral gradients in stratification (not shown) and stress (Figure 14b), with higher stresses landward of the front. SSC was elevated on the banks landward of the front where stresses were high and the bed material erodible (Figure 14c). 
(a)

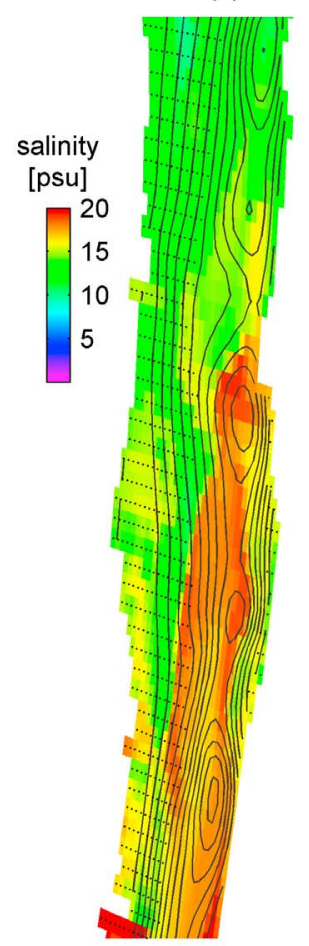

(b)

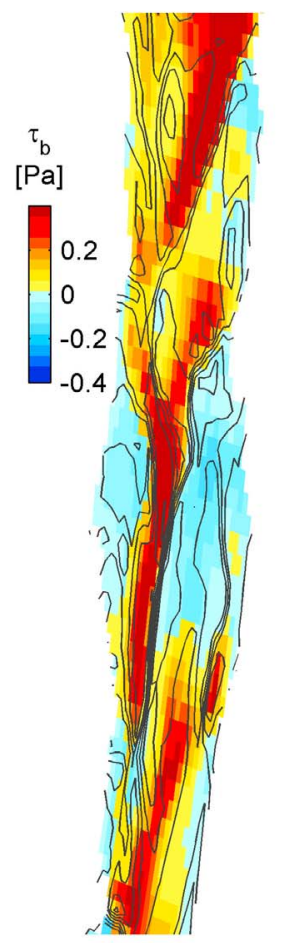

(c)

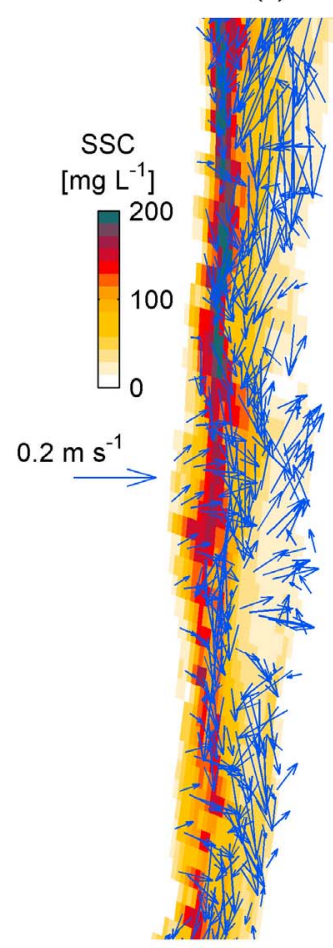

(d)

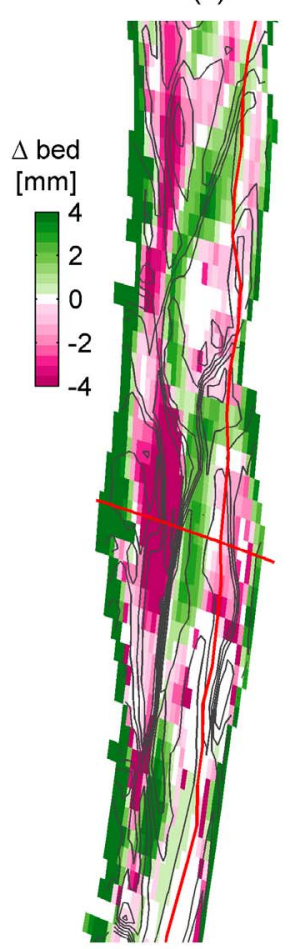

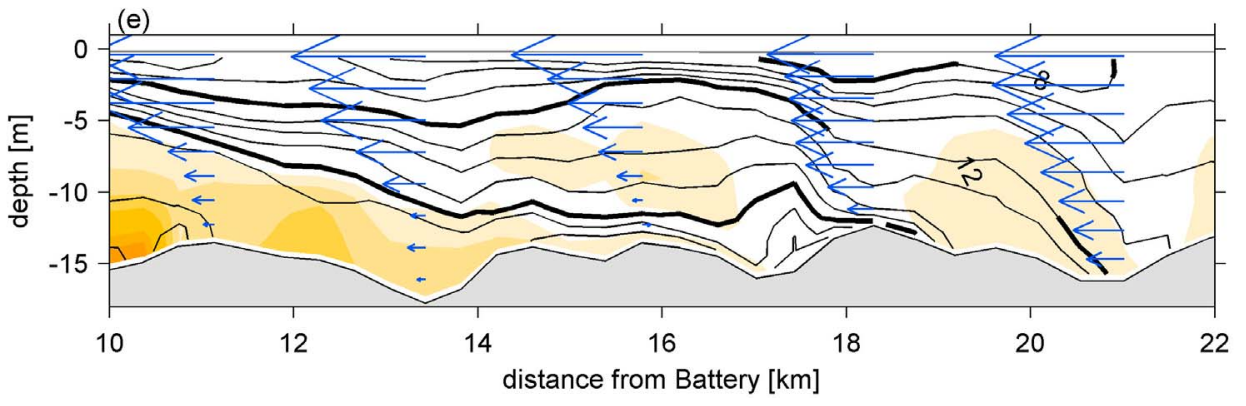

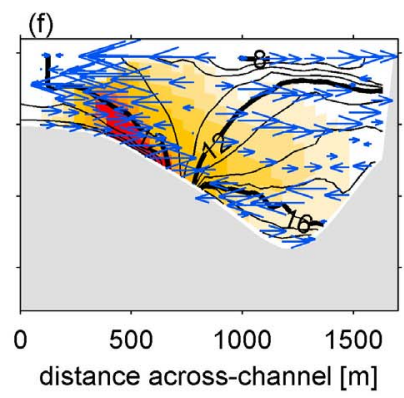

Figure 14. Sediment trapping at George Washington Bridge front in the lower ETM. Instantaneous model fields of (a) bottom salinity, (b) bed stress, and (c) SSC at the beginning of a flood tide (day 310), and (d) change in bed elevation over the subsequent tidal cycle. In Figure 14a contours are of bathymetry, and stippling shows grid cells that are shallower than the mean cross-sectional depth and considered "shoals." In Figures $14 \mathrm{~b}$ and $14 \mathrm{~d}$, contours are of bottom salinity to highlight location of the salinity front, and in Figure 14c arrows show near bottom velocities. (e) Along-channel and (f) across-channel sections of SSC, salinity (contours), and velocity (arrows). Location of along- and across-channel sections are shown as red lines in Figure 14d.

[46] As in the upper estuary, the convergence of nearbottom velocities at lateral salinity gradients correspond with regions of deposition at tidal time scales (Figure 14d). At this time, the banks of the channel were depositional and the shoals were erosional, with the transition occurring around the isobath where the front intersected the bottom. During subsequent tides as the salinity intrusion moved up-estuary and the pycnocline rose higher in the water column, the lateral front moved up the banks onto the shoal, continuing with the pattern of deposition on the seaward, or channel side of the front. This deposition at lateral fronts helps to produce the erodible bed on the shoals of the lower estuary, even though the shoreline perturbations that generate the fronts are relatively subtle. Deposition of erodible material on the shoals during neaps is necessary to create the lower ETM during the higher bed stresses of spring tides.

\section{Summary and Discussion}

[47] One of the primary results from both the observations and model is that the estuarine sediment flux is highly segregated laterally, with landward flux in the channel and seaward flux on the shoals. The channel-shoal asymmetry in net sediment flux is consistent with other observations [Panuzio, 1965; Scully and Friedrichs, 2007], and the model results over a wide range of forcing suggest that it may be a general feature. Baroclinic convergence and stratification gradients in the channel trap sediment, and correspondingly the estuary might be expected to fill with sediment [Meade, 
1969; Schubel and Hirschberg, 1978]. Instead, many estuaries appear to be near morphodynamic equilibrium, with accumulation rates approximately equal to the changing accommodation space due to sea level rise or dredging [Meade, 1969; Olsen et al., 1993]. If watershed sediment supply exceeds the accommodation space, yet processes in the channel continue to efficiently trap sediment, then sediment export on the shoals is a necessary component of the long-term estuarine sediment budget.

[48] In the Hudson, the long-term rates of sediment accumulation roughly correspond with the rate of sea level rise of 1-3 $\mathrm{mm} \mathrm{yr}^{-1}$ [Olsen et al., 1978; Hirschberg et al., 1996; McHugh et al., 2004; Klingbeil and Sommerfield, 2005; Slagle et al., 2006]. The sediment supply from the watershed exceeds the mass to fill the accommodation space, so sediment must be conveyed through the estuary to the coastal ocean [McHugh et al., 2004; Klingbeil and Sommerfield, 2005]. The results here suggest that the shoals provide the primary pathway for this seaward flux. A simpler model of sediment transport capacity in the Hudson came to similar conclusions [Ralston and Geyer, 2009]. The lateral partitioning of sediment flux in that model assumed morphodynamic equilibrium to infer the bed erodibility parameter, and yet the pattern of sediment fluxes found in that model [Ralston and Geyer, 2009, Figure 12] was similar to the results here (Figure 8).

[49] A second key result, again in both the observations and model, is that bottom salinity fronts associated with bathymetric features at multiple locations along the estuary provide a mechanism for sediment trapping. While this has long been recognized for the head of salinity intrusion, here we find that multiple, topographically locked fronts also lead to sediment convergence and enhanced deposition. A similar process of sediment trapping tied to a bathymetric front rather than the large scale salinity intrusion was noted at a constriction in San Francisco Bay [Schoellhamer, 2000]. The effectiveness of frontal trapping depends in part on the availability of suspended sediment. At some locations in the Hudson, the local supply is eroded from adjacent unstratified shoals, while at other locations the eroded material was previously deposited in the channel landward of the front.

[50] Along-estuary gradients in bathymetry lead to frontal formation, but the effect of the resulting stratification on the sediment dynamics varies. Specifically, the elevation of the shoals relative to the pycnocline appears to be key. Stratification is created in the channel, and the extent to which it spreads to the shoals affects the lateral gradient in bed stress. The elevation of the pycnocline depends on the balance between the along-estuary density gradient and tidal mixing [Stacey and Ralston, 2005], and thus varies through the spring-neap cycle and with distance along the estuary. The Hudson has distinct regions: wide sections with shallow shoals that are unstratified when the channel is stratified, and narrower sections with deeper shoals that are below the pycnocline for much of the spring-neap cycle. For the former, as in Tappan Zee and Haverstraw Bay, the channels are depositional and the shoals are erosional during neap tides, with the opposite during springs. On the deeper shoals of the lower estuary, neap tides are depositional and spring tides erosional.

[51] The sediment model incorporated field data through the initial bed distribution and through comparisons with observations in Haverstraw Bay, but additional model-data comparison is needed to test its quantitative fidelity. The model reproduced known features in the Hudson, including high SSC on the shoals of the lower ETM [Geyer et al., 2001; Traykovski et al., 2004] and high rates of deposition in the channel of Haverstraw Bay [Nitsche et al., 2010]. However, maximum SSC in the model were lower than have been observed, both in the lower ETM and at fronts in Haverstraw. One aspect of the discrepancy may be the sediment supply from the river. In the model, sediment was input with river discharge, but much of that fluvial sediment deposited in the tidal freshwater region rather than reaching the estuary. In the observations, SSC (for a given shear stress) increased about a week after the discharge event, perhaps due to the introduction of new sediment that was relatively easy to remobilize. Sediment transport in the tidal river depends on how sediment properties (settling velocity, erodibility parameter, critical shear stress) are modified from the river to the estuary, and remains a general research topic.

[52] Topographically locked bottom salinity fronts along the estuary appear to be important for sediment trapping at tidal time scales and for creating lateral gradients in stratification that affect erosion and deposition, but they do not necessarily correspond with classical ETMs. Convergence at the fronts did increase SSC locally, but over the entire estuary and range of tidal forcing, the highest SSC corresponded with the highest bed stresses, which occurred in narrow parts of the estuary (Figure 7). The lower ETM had strong frontal trapping, but bedrock constraints of the Palisades narrow the estuary such that sediment deposited on the shoals during neap tides was remobilized during springs. Similarly in the narrow Hudson Highlands of the upper estuary ( $\sim 60$ to $80 \mathrm{~km}$ ), deposition occurred at fronts during neaps (Figure 11), but the highest concentrations occurred during spring tides due to elevated bed stresses ( $\sim 60$ to $80 \mathrm{~km}$ ) (Figure 7); observational evidence is needed to evaluate these model results in the narrow upper estuary.

[53] The model results suggest lateral and longitudinal bathymetric variability modifies the conceptual framework for estuarine sediment trapping at a single ETM at the head of salt. Instead, sediment trapping occurs simultaneously at multiple frontal locations along the estuary. Sediment that is trapped at fronts deposits in regions of lower stress, which can be either in the channel or on the shoals depending on the elevation of the pycnocline relative to the depth of the shoals. Much of the sediment deposited at fronts during neap tides is resuspended by the higher stresses of spring tides, and the highest concentrations in the estuary occur where bathymetric constraints create the highest stresses. Thus high SSC is most likely where both trapping and resuspension occur, which in the Hudson is the laterally constrained lower ETM.

[54] While the temporally averaged sediment fluxes suggest sharp segregation between channel and shoals (Figure 10), at tidal time scales the lateral exchange of sediment is complex (Figures 13 and 14). Lateral circulation and sediment fluxes can be driven by a number of factors, including channel curvature, Coriolis, and lateral density gradients [Fugate et al., 2007; Kim and Voulgaris, 2008; Chen and Sanford, 2009]. The mechanisms driving the lateral fluxes depend on salinity (stratification and horizontal density gradients) and local bathymetry, and thus vary along 
the estuary and through the spring-neap cycle. Lateral fluxes associated with the topographic bottom salinity fronts appear to be important for creation of secondary ETMs, but more investigation is needed on lateral trapping at tidal timescales.

[55] In the wide region of Tappan Zee and Haverstraw Bay, sediment trapping occurs at fronts, but sediment concentrations are much less than in the lower ETM. The model suggests that frontal deposition occurs on the channel banks, which may provide a fundamental morphological feedback. If the morphology is relatively unconstrained by the geologic framework, deposition may continue at the interface between channel and shoals until the bed of the shoals is located above the pycnocline, and therefore less able to trap sediment. Lateral trapping in the lower estuary does not fill in the shoals to the same depth because of the competing morphological constraint of a narrow geologic framework and high stresses from the tidal volume flux, particularly during spring tides. The feedbacks among stratification, baroclinic trapping, and estuarine morphology that produce the spatial heterogeneity in SSC in the Hudson may be generally applicable, and should be tested with observations and modeling in other estuaries.

[56] Acknowledgments. This research was funded by a grant from the Hudson River Foundation (\#002/07A). D.R. was partially supported by the Office of Naval Research (N00014-08-1-0846). We thank Gary Wal (USGS, New York Water Science Center) for the Poughkeepsie gauging station data and Frank Nitsche (Lamont-Doherty) for the benthic mapping data.

\section{References}

Bokuniewicz, H. J., and C. L. Arnold (1984), Characteristics of suspended sediment transport in the lower Hudson River, Northeast. Environ. Sci. 3(3/4), 184-189.

Burchard, H., and H. Baumert (1998), The formation of estuarine turbidity maxima due to density effects in the salt wedge. A hydrodynamic process study, J. Phys. Oceanogr., 28(2), 309-321, doi:10.1175/15200485(1998)028<0309:TFOETM $>2.0$. CO; 2

Chen, S.-N., and L. P. Sanford (2009), Lateral circulation driven by boundary mixing and the associated transport of sediments in idealized partially mixed estuaries, Cont. Shelf Res., 29(1), 101-118, doi:10.1016/j. csr.2008.01.001.

Ellsworth, J. M. (1986), Sources and sinks for fine-grained sediment in the lower Hudson River, Northeast. Geol., 8(3), 141-155.

Fugate, D. C., C. T. Friedrichs, and L. P. Sanford (2007), Lateral dynamics and associated transport of sediment in the upper reaches of a partially mixed estuary, Chesapeake Bay, USA, Cont. Shelf Res., 27(5), 679-698, doi:10.1016/j.csr.2006.11.012.

Geyer, W. (1993), The importance of suppression of turbulence by stratification on the estuarine turbidity maximum, Estuaries Coasts, 16(1) 113-125, doi: $10.2307 / 1352769$.

Geyer, W. R., R. P. Signell, and G. C. Kineke (1998), Lateral trapping of sediment in partially mixed estuary, in Physics of Estuaries and Coastal Seas: Proceedings of the 8th International Biennial Conference on Physics of Estuaries and Coastal Seas, Edited by J. Dronkers and M. Scheffers, pp. 115-124, A. A. Balkema, Rotterdam, Netherlands.

Geyer, W. R., J. D. Woodruff, and P. Traykovski (2001), Sediment transport and trapping in the Hudson River estuary, Estuaries, 24(5), 670 679, doi:10.2307/1352875.

Haidvogel, D. B., et al. (2008), Ocean forecasting in terrain-following coordinates: Formulation and skill assessment of the Regional Ocean Modeling System, J. Comput. Phys., 227(7), 3595-3624, doi:10.1016/j. jcp.2007.06.016.

Hamblin, P. F. (1989), Observations and model of sediment transport near the turbidity maximum of the upper Saint Lawrence estuary, J. Geophys. Res., 94(C10), 14,419-14,428, doi:10.1029/JC094iC10p14419.

Hirschberg, D. J., P. Chin, H. Feng, and J. K. Cochran (1996), Dynamics of sediment and contaminant transport in the Hudson River estuary: Evidence from sediment distributions of naturally occurring radionuclides, Estuaries, 19(4), 931-949, doi:10.2307/1352309.

Jay, D. A., and J. D. Musiak (1994), Particle trapping in estuarine tidal flows, J. Geophys. Res., 99(C10), 20,445-20,461, doi:10.1029/94JC00971.
Kim, Y. H., and G. Voulgaris (2008), Lateral circulation and suspended sediment transport in a curved estuarine channel: Winyah Bay, SC, USA, J. Geophys. Res., 113, C09006, doi:10.1029/2007JC004509.

Klingbeil, A. D., and C. K. Sommerfield (2005), Latest Holocene evolution and human disturbance of a channel segment in the Hudson River Estuary, Mar. Geol., 218(1-4), 135-153, doi:10.1016/j.margeo.2005.02.026.

Lerczak, J. A., W. R. Geyer, and R. J. Chant (2006), Mechanisms driving the time-dependent salt flux in a partially stratified estuary, J. Phys. Oceanogr. 36(12), 2296-2311, doi:10.1175/JPO2959.1.

Lin, J., and A. Y. Kuo (2001), Secondary turbidity maximum in a partially mixed microtidal estuary, Estuaries, 24(5), 707-720, doi:10.2307/1352879.

McHugh, C. M. G., S. F. Pekar, N. Christie-Blick, W. B. F. Ryan, S. Carbotte, and R. Bell (2004), Spatial variations in a condensed interval between estuarine and open-marine settings: Holocene Hudson River estuary and adjacent continental shelf, Geology, 32(2), 169-172, doi:10.1130/G20150.1.

Meade, R. H. (1969), Landward transport of bottom sediments in estuaries of the Atlantic Coastal Plain, J. Sediment. Petrol., 39(1), 222-234.

Menon, M. G., R. J. Gibbs, and A. Phillips (1998), Accumulation of muds and metals in the Hudson River estuary turbidity maximum, Environ. Geol., 34(2), 214-222, doi:10.1007/s002540050273.

Nichols, M. M. (1972), Sediments of the James River estuary, Mem. Geol. Soc. Am., 133, 169-212.

Nichols, M., and G. Poor (1967), Sediment transport in a coastal plain estuary, J. Waterw. Harbors Div. Proc. Am. Soc. Civ. Eng., 93(WW4), 83-95.

Nitsche, F. O., W. B. F. Ryan, S. M. Carbotte, R. E. Bell, A. Slagle, C. Bertinado, R. Flood, T. Kenna, and C. McHugh (2007), Regional patterns and local variations of sediment distribution in the Hudson River Estuary, Estuarine Coastal Shelf Sci., 71(1-2), 259-277, doi:10.1016/j. ecss.2006.07.021

Nitsche, F. O., T. C. Kenna, and M. Haberman (2010), Quantifying 20th century deposition in complex estuarine environment: An example from the Hudson River, Estuarine Coastal Shelf Sci., 89(2), 163-174, doi:10.1016/j.ecss.2010.06.011.

North, E., and E. Houde (2001), Retention of white perch and striped bass larvae: Biological-physical interactions in Chesapeake Bay estuarine turbidity maximum, Estuaries Coasts, 24(5), 756-769, doi:10.2307/ 1352883.

Olsen, C. R. (1979), Radionuclides, sedimentation and the accumulation of pollutants in the Hudson River Estuary., PhD thesis, Columbia Univ., New York.

Olsen, C. R., H. J. Simpson, R. F. Bopp, S. C. Williams, T. H. Peng, and B. L. Deck (1978), A geochemical analysis of the sediments and sedimentation in the Hudson Estuary, J. Sediment. Res., 48(2), 401-418.

Olsen, C. R., I. L. Larsen, P. J. Mulholland, K. L. von Damm, J. M. Grebmeier, L. C. Schaffner, R. J. Diaz, and M. M. Nichols (1993), The concept of an equilibrium surface applied to particle sources and contaminant distributions in estuarine sediments, Estuaries, 16(3), 683-696, doi:10.2307/1352805.

Panuzio, F. L. (1965), Lower Hudson River siltation, in Proceedings of the 2nd Federal Interagency Sedimentation Conference, Misc. Publ. 970 pp. 512-550, Agric. Res. Serv., U.S. Dep. of Agric., Washington, D. C.

Postma, H. (1967), Sediment transport and sedimentation in the estuarine environment, in Estuaries, pp. 158-179, Am. Assoc. for the Adv. of Sci., Washington, D. C.

Ralston, D. K., and W. R. Geyer (2009), Episodic and long-term sediment transport capacity in the Hudson River estuary, Estuaries Coasts, 32, 1130-1151, doi:10.1007/s12237-009-9206-4

Ralston, D. K., W. R. Geyer, and J. A. Lerczak (2008), Subtidal salinity and velocity in the Hudson River estuary: Observations and modeling, J. Phys. Oceanogr., 38(4), 753-770, doi:10.1175/2007JPO3808.1.

Roberts, W. P., and J. W. Pierce (1976), Deposition in upper Patuxent estuary, Maryland, 1968-1969, Estuarine Coastal Mar. Sci., 4(3), 267-280, doi:10.1016/0302-3524(76)90060-8.

Schoellhamer, D. H. (2000), Influence of salinity, bottom topography, and tides on locations of estuarine turbidity maxima in northern San Francisco Bay, in Coastal and Estuarine Fine Sediment Processes, Proc. Mar. Sci., vol. 3, edited by W. H. McAnally and A. J. Mehta, pp. 343-357, Elsevier, New York.

Schubel, J. R., and D. J. Hirschberg (1978), Estuarine graveyards, climatic change, and the importance of the estuarine environment, in Estuarine Interactions, pp. 285-303, Academic, San Diego, Calif.

Scully, M. E., and C. T. Friedrichs (2007), Sediment pumping by tidal asymmetry in a partially mixed estuary, J. Geophys. Res., 112, C07028, doi:10.1029/2006JC003784.

Shchepetkin, A. F., and J. C. McWilliams (2005), The regional oceanic modeling system (ROMS): A split-explicit, free-surface, topographyfollowing-coordinate oceanic model, Ocean Modell., 9(4), 347-404, doi:10.1016/j.ocemod.2004.08.002. 
Slagle, A. L., W. B. F. Ryan, S. M. Carbotte, R. Bell, F. O. Nitsche, and T. Kenna (2006), Late-stage estuary infilling controlled by limited accommodation space in the Hudson River, Mar. Geol., 232(3-4), 181-202, doi:10.1016/j.margeo.2006.07.009.

Sommerfield, C. K., and K.-C. Wong (2011), Mechanisms of sediment flux and turbidity maintenance in the Delaware Estuary, J. Geophys. Res. 116, C01005, doi:10.1029/2010JC006462.

Stacey, M. T., and D. K. Ralston (2005), The scaling and structure of the estuarine bottom boundary layer, J. Phys. Oceanogr., 35(1), 55-71, doi:10.1175/JPO-2672.1.

Traykovski, P., R. Geyer, and C. Sommerfield (2004), Rapid sediment deposition and fine-scale strata formation in the Hudson estuary, J. Geophys Res., 109, F02004, doi:10.1029/2003JF000096.
Wall, G., E. Nystrom, and S. Litten (2008), Suspended sediment transport in the freshwater reach of the Hudson River estuary in eastern New York, Estuaries Coasts, 31(3), 542-553, doi:10.1007/s12237-008-9050-y.

Warner, J. C., W. R. Geyer, and J. A. Lerczak (2005), Numerical modeling of an estuary: A comprehensive skill assessment, J. Geophys. Res., 110, C05001, doi:10.1029/2004JC002691.

Warner, J. C., C. R. Sherwood, R. P. Signell, C. K. Harris, and H. G. Arango (2008), Development of a three-dimensional, regional, coupled wave, current, and sediment-transport model, Comput. Geosci., 34(10), 1284-1306, doi:10.1016/j.cageo.2008.02.012.

Woodruff, J. D. (1999), Sediment deposition in the lower Hudson River estuary, M.S. thesis, Mass. Inst. of Technol./Woods Hole Oceanogr. Inst. Woods Hole. 